Article

\title{
A Framework to Achieve Multifunctionality in Biomimetic Adaptive Building Skins
}

\author{
Aysu Kuru ${ }^{1, * \mathbb{D}}$, Philip Oldfield ${ }^{1}\left(\mathbb{D}\right.$, Stephen Bonser ${ }^{2}$ and Francesco Fiorito ${ }^{1,3} \mathbb{D}$ \\ 1 Faculty of Built Environment, University of New South Wales, Sydney, NSW 2052, Australia; \\ p.oldfield@unsw.edu.au (P.O.); f.fiorito@unsw.edu.au (F.F.) \\ 2 School of Biological, Earth and Environmental Sciences, University of New South Wales, \\ Sydney, NSW 2052, Australia; s.bonser@unsw.edu.au \\ 3 Department of Civil, Environmental, Land, Building Engineering and Chemistry, \\ Polytechnic University of Bari, 70126 Bari, Italy \\ * Correspondence: a.kuru@unsw.edu.au or aysuek@gmail.com
}

Received: 5 May 2020; Accepted: 23 June 2020; Published: 27 June 2020

check for updates

\begin{abstract}
Building skins should host multiple functions for increased performance. Addressing this, their design can benefit by learning from nature to achieve multifunctionality, where multifunctional strategies have evolved over years. However, existing frameworks to develop biomimetic adaptive building skins (Bio-ABS) have limited capabilities transferring multifunctionality from nature into designs. This study shows that through investigating the principles of hierarchy and heterogeneity, multifunctionality in nature can be transferred into biomimetic strategies. We aim at mapping the existing knowledge in biological adaptations from the perspective of multifunctionality and developing a framework achieving multifunctionality in Bio-ABS. The framework is demonstrated through the case study of Echinocactus grusonii implemented as a Bio-ABS on a digital base-case building. The methods include the Bio-ABS case study demonstrating the framework and simulating the performance of the case study and base-case building to comparatively analyze the results. The outcomes are a framework to develop multifunctional Bio-ABS and simulation results on the performance improvement Bio-ABS offer. The performance comparison between the Bio-ABS and base-case building show that there is a decrease in the discomfort hours by a maximum of $23.18 \%$. In conclusion, translating heterogeneity and hierarchy principles in nature into engineered designs is a key aspect to achieve multifunctionality in Bio-ABS offering improved strategies in performance over conventional buildings.
\end{abstract}

Keywords: biomimetics; building skin; multifunctionality; architectural design; building envelope; adaptability; design framework; building performance simulation

\section{Introduction}

Building design has advanced through technological developments, making the design and realization of innovative structures possible using new materials and construction techniques [1]. These breakthroughs in architecture helped building parts to host diverse functions, such as external walls shifting from being mostly load-bearing structures to having alternative roles [2]. The building skin now primarily acts as a thermal, acoustic, and visual barrier between the exterior and interior [3]. This change has seen the building skin heavily influence the building performance [4]. In response, new technologies including biomimetic adaptive building skins (Bio-ABS) are emerging that can adapt to changing environmental conditions, foster increased comfort, and reduce operational carbon emissions $[5,6]$. 
Using biological functions to design technical systems is called biomimetics $[7,8]$. Biomimetics is used in developing Bio-ABS, due to the opportunities in transferring biological adaptations into the design of climate-adaptable buildings [9-11]. There is extensive research in transferring biological adaptations into Bio-ABS with multiple frameworks and case studies [12-18]. Some of these frameworks are supported with resources such as databases or linguistic approaches [16,18-23]. Despite such developments, there is still a need for defining strategies to translate multifunctional strategies from nature into Bio-ABS, because environmental regulation in buildings often requires having multiple functions $[5,24,25]$. Most published works explore developing biomimetic strategies focusing on environmental adaptability, but are limited in addressing multifunctionality $[10,26]$.

Multifunctional mechanisms in nature is achieved through the "natural design principles" including heterogeneity and hierarchy [27-29]. Organisms have developed multi-layered structures (hierarchy) with different morphologies of basic components (heterogeneity) to achieve multifunctionality [29-32]. This paper aims at structuring and mapping the existing knowledge in biological adaptations from the perspective of multifunctionality and developing a design framework to achieve multifunctionality in Bio-ABS. To do so, we provide (1) an understanding of how to achieve multifunctionality in building skin design through hierarchy and heterogeneity, (2) a systematic classification of multifunctional properties in biological systems, (3) a framework for developing multifunctional Bio-ABS, and (4) a case study of Echinocactus grusonii demonstrating the framework.

\section{Existing Biomimetic Design Frameworks to Develop Bio-ABS}

Several biomimetic design frameworks to develop Bio-ABS have been developed supported with case studies [16,18-23]. Most of these frameworks have focused on biological adaptations, being the main purpose of Bio-ABS $[9,12,13,33]$. However, it is important to fulfill multiple functional requirements in buildings for improved performance. There is limited exploration of this in the literature. However, nature offers ways to achieve multifunctionality, named the "natural design principles", yet to be significantly investigated in biomimetic design [30]. In this section, we review and discuss the existing biomimetic design frameworks to develop Bio-ABS regarding to what extent multifunctionality is addressed.

Most biomimetic design frameworks are applicable for use in architecture and some specialized to design Bio-ABS. All frameworks comprise of phases either starting with a technical problem followed by a biological solution (TD) or starting with a biological solution followed by a technical problem (BU), and all ending with developing a biomimetic strategy (Table 1). Some include databases to search for biological adaptations. The ones with no databases provide other means of investigation including linguistic approaches to define commonalities between nature and design, systematic analogical translation to find biological systems [18,22,23,34-37].

Biomimetic principles for the development of adaptive architectural envelopes, is based on understanding plants adaptations at macro- and micro-scales to be abstracted into adaptive architectural envelopes [13]. The framework focuses on dynamic mechanisms responding to external stimuli through movement and static strategies with surface properties. A case study developed using the framework is an adaptive architectural envelope inspired by plants genus Mesembryanthemum where seeds swell with rain [9]. The design is triggered by rainwater as an opening system [13]. The opportunity in this framework is addressing diversity in biological scales relating to hierarchy. This framework only considers plant adaptations; therefore, it is exclusive of other living systems in different kingdoms. Moreover, the mechanisms investigated are only triggered by external environmental influences limiting the diversity in biological domain. Most importantly, this framework has not specified how to combine multiple functions, either a combination of static and dynamic or otherwise. 
Table 1. List of existing biomimetic design frameworks (TD: Top-down, BU: Bottom-up).

\begin{tabular}{|c|c|c|c|c|}
\hline Reference & Biomimetic Design Framework & TD & BU & Database \\
\hline [20] & BioTRIZ & $\checkmark$ & & $\checkmark$ \\
\hline [36] & Design Spiral-Helix Model & $\checkmark$ & & \\
\hline [37] & $\begin{array}{c}\text { Computational Architectural Design Based on Biological } \\
\text { Principles }\end{array}$ & $\checkmark$ & & \\
\hline [38] & Bioinspired Environmental Architectural Design & $\checkmark$ & & $\checkmark$ \\
\hline [39] & BioGEN & $\checkmark$ & & $\checkmark$ \\
\hline [34] & BioMAPS & $\checkmark$ & & \\
\hline [40] & Ecomimetic & $\checkmark$ & & \\
\hline [41] & New Product Development Process & $\checkmark$ & & \\
\hline [42] & The Law of System Completeness & $\checkmark$ & & $\checkmark$ \\
\hline [43] & Idea-Inspire & $\checkmark$ & & $\checkmark$ \\
\hline [44] & Design by Analogy to Nature Engine (DANE) & $\checkmark$ & & $\checkmark$ \\
\hline [45] & Biomimicry Theoretical Model & & $\checkmark$ & \\
\hline [13] & $\begin{array}{c}\text { Biomimetic Principles for the Development of Adaptive } \\
\text { Architectural Envelopes }\end{array}$ & & $\checkmark$ & \\
\hline [46] & $\begin{array}{c}\text { Transferring Plant Movements to Elastic Systems in } \\
\text { Architecture }\end{array}$ & & $\checkmark$ & \\
\hline [17] & Biomimicry 3.8 & $\checkmark$ & $\checkmark$ & $\checkmark$ \\
\hline [35] & Typological Analysis & $\checkmark$ & $\checkmark$ & \\
\hline [22] & Analogical Translation & $\checkmark$ & $\checkmark$ & \\
\hline [23] & Nature Studies Analysis & $\checkmark$ & $\checkmark$ & \\
\hline [47] & Ecosystem for Biomimetic Design & $\checkmark$ & $\checkmark$ & \\
\hline [18] & Engineering-to-Biology Thesaurus & $\checkmark$ & $\checkmark$ & \\
\hline
\end{tabular}

Transferring plant movements to elastic systems is used to develop kinetic elastic architectural systems inspired by plant movements [46]. A case study developed using this framework is Flectofin ${ }^{\mathrm{TM}}$, a shading prototype inspired by the petal movements of the bird of paradise flower [48]. The device is a hingeless louver system unfolding through a force. The success of this framework is investigating and transferring dynamic adaptations in nature into architecture. This framework only focused on plant movements and mechanical efficiency, it is limited in terms of multifunctionality. It could be, if it investigates environmental triggers informing movements in nature, to develop Bio-ABS. However, currently, the biological domain and biomimetic output can be triggered by the same stimulus, but they may not host the same function. For example, petals of the bird of paradise flower move for pollination, but Flectofin ${ }^{\mathrm{TM}}$ moves to provide shading. Moreover, this framework does not address how to integrate multiple functions together. For example, would it be possible to combine two types of plant(s) movements hosting different purposes and how?

"BioTRIZ" is a problem-solving method undertaken via a database of biological data [20,21]. The database's purpose is to make biological information available in a language specific to engineering. However, the process is out of biological context, meaning the strategies do not exist in nature, but as theoretical ideas. For example, the surface segmentation trend is observed in nature as naturally transparent ridged surfaces refracting light and becoming colored due to nanostructures. Such as the Menelaus butterfly (Morpho menelaus) has transparent wings which look blue with sunlight. This property could be transferred into functional surface structures. The success of this framework is introducing heterogeneity through generalizing concepts. The limitation is the absence of the biological solution and multifunctionality is not addressed. It could be, if this framework integrates how to achieve multifunctionality in addition to identifying heterogeneity in nature.

"Biomimicry 3.8" offers a framework accompanied with an online database of biological strategies, called AskNature [17]. AskNature contains over 1600 biological strategies and provides a taxonomy to organize biological adaptations [19]. The steps applied in the process are called the "Design Spiral". The success of this framework is the database accessible to everyone, as a key aspect in investigating biological strategies. The difficulty in adopting this framework is the lack of clarification in some stages; 
abstract, emulate, and evaluate. The abstraction stage is described as brainstorming ideas from nature; emulation as seeking expert advice and evaluation as integrating life's principles. These measures are often complex and may be challenging for every design. The limitation of this framework is the lack of integrating multifunctionality. It could be, if the AskNature database provides multifunctional properties of organisms be used to design multifunctional strategies. This may require adding a step in the 'Design Spiral' on achieving multifunctionality.

'BioGen' is another biomimetic design framework [10,41]. It creates an exploration model mapping functional aspects, relevant processes and influencing factors. The biological entities called pinnacles are presented as examples for a specific function or process. An example of a case study developed by using BioGen is the Shading/Energy Generating Skin, inspired by plants tracking sun radiation, designed to tilt according to the angle of the sun [49]. While the creator of BioGen has proposed a discussion on multi-regulation of the four environmental factors (heat, light, water, and air) this is a theoretical approach and lacks further development. Multi-regulation is addressed by mapping biological functions of the same living system regulating multiple environmental factors dependently, i.e., ventilation is associated with heat regulation. This presents a success in addressing multifunctionality, but its applicability is limited and must be fulfilled with examples. It may also benefit addressing multifunctionality through combining functions of different living systems (inter)dependently.

DANE is another framework exploring analogical reasoning in biomimetics [44]. DANE follows the steps of defining the problem, searching for the biological solution, and applying the principle [50]. An example to this approach is the Shark Attack Project, designed to protect swimmers from sharks. It is inspired by pistol shrimp's snapping mechanism that creates a sound. The design was a shark repellant emitting sounds. The success in this framework is the identification of biological functions that gives clues on the heterogeneous properties of organisms. The limitation is addressing multifunctionality, either analogically or as design outcomes.

\section{Achieving Multifunctionality through Natural Design Principles}

During the course of evolution, living systems adapted their character to meet changing environmental conditions by multifunctional strategies [30]. The result is a compromise satisfying partially conflicting requirements; known as trade-offs [51,52]. A trade-off is having multiple functions through diminishing one property in return for gains in others [53]. The functional requirements of conventional buildings are complex and often contradictory and during the life cycle of a building, they must be adapted to changes [54,55]. Some examples of these functional requirements include decreasing solar gains, while providing views and improving illuminance levels $[26,56,57]$. These strategies are still mostly handled as isolated components that are monofunctional. One way to address this challenge is using biomimetics, as in nature, multifunctional trade-off strategies have been developed through evolution [58]. Multifunctionality is well understood in biology; however, its translation into architecture remains limited [24]. In this section, we present and discuss opportunities to achieve multifunctionality in biomimetics through the "natural design principles" (Figure 1). We include hierarchy (multi-scale) and heterogeneity (multidimension) and adaptability in this study. Beyond this, there remain opportunities to explore multifunctionality through other processes including anisotropy, redundancy, and more [59].

\subsection{Adaptability in Nature and Bio-ABS}

Adaptability is the ability of an organism to respond to changing internal or external conditions [60]. Most organisms have evolved various morphological, physiological, and behavioral adaptations to survive in their habitats. For example, plants exchange water vapor to decrease their internal temperatures during hot periods through their stomata. This is a means of diffusing useful gases for photosynthesis and to discharge excess materials to dissipate heat [61]. Depending on the natural habitat, stomata show various adaptations [62] (Figure 2). In some plants such as cacti and succulents, 
stomata are positioned on the epidermal (outmost) layer of the stem as they have minimal leaves to maintain a low surface to volume ratio. While in most plants, stomata are located on the leaves to ease the process of photosynthesis. The number of stomatal openings varies in different species according to the climatic influences as stoma loses water. For instance, desert plants lack in stomata while tropical plants have higher numbers of stomata [62-64].

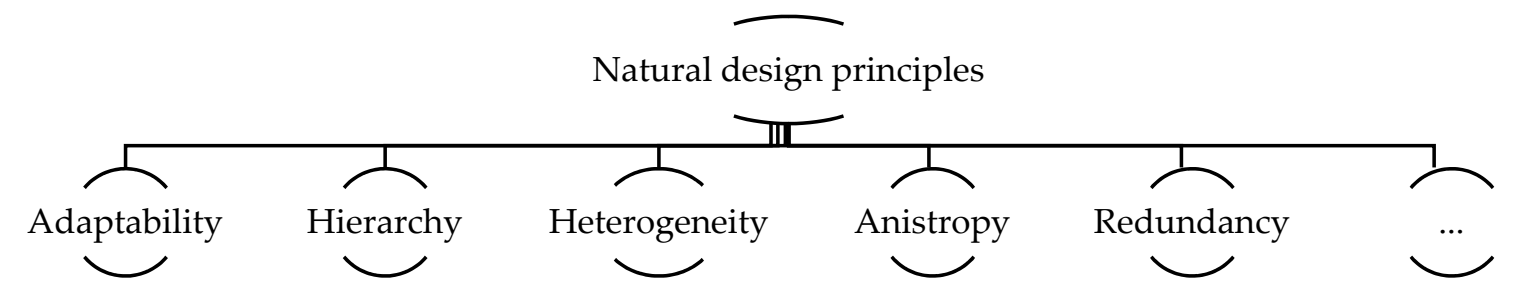

Figure 1. Some of the natural design principles as an ever-growing classification, where the last item in the list presents continuity.
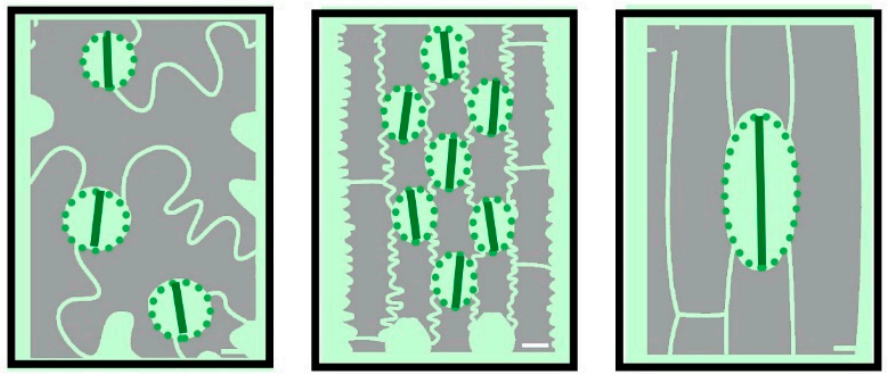

Figure 2. Stomatal adaptations in plants by changing size and density.

In engineering and design this is different, where a system is often designed to achieve one function and it does not reconfigure itself. Therefore, the strategy is static, where a design is made and must satisfy all needs during the lifetime [13]. However, adaptability in building skins learnt from nature is an emerging topic with many examples. Some examples of Bio-ABS include the Homeostatic Façade System that is an adaptive shading component, changing its shape according to solar radiation levels [65]. Also, the Ocean Pavilion, a full-scale application of the shading device Flectofin ${ }^{\mathrm{TM}}$, regulates solar irradiance levels by an automated hingeless mechanism [66] (Figure 3). Other examples, the HygroScope and HygroSkin, can change their morphologies through the changes in humidity by hygroscopic material properties of wood $[67,68]$.
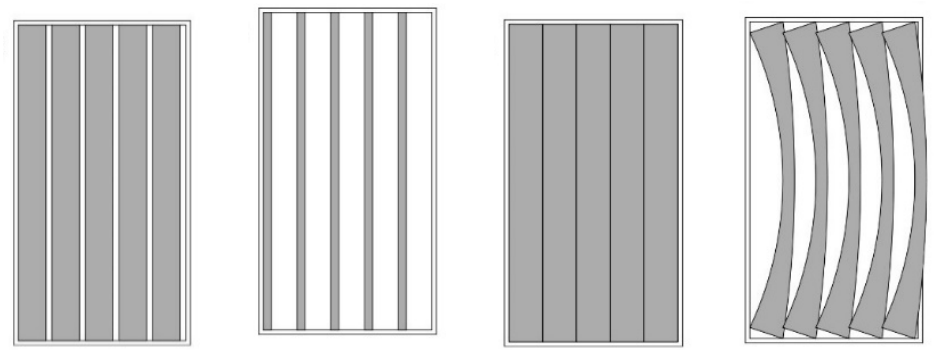

Figure 3. Schematic illustrations of some Bio-ABS examples, from left to right; the Ocean Pavilion in closed and open configurations, and Flectofin ${ }^{\mathrm{TM}}$ in closed and open configurations.

\subsection{Achieving Multifunctionality through a Multi-Scaled Hierarchy}

Hierarchy is having functional features in a multi-level structure from nano-to-macro scales. Having differentiated scales allows organisms to develop multiple functional adaptations at various levels. For example, adapting the form of an organ such as a tree branch is one level of adaptation, and a second is the microstructures of the tree bark's material [69] (Figure 4). This dual optimization 
is well known as a strategy for solving engineering problems. This approach can be combined with adaptability and achieve multifunctionality in Bio-ABS. An example to hierarchy in nature is seen in trees. The shape of a branch is created by the assembly of molecules to cells and of cells to wood with a specific shape. Therefore, at every scale, the branch is both form and material, where the materials compose the form; therefore, the biological structure becomes hierarchical [70]. It is important to note that tree bark and tannins is categorized under hierarchy due to being a material at a small scale covering the larger scaled tree bark. The adaptations of tannins are dependent on its scale, not its form.

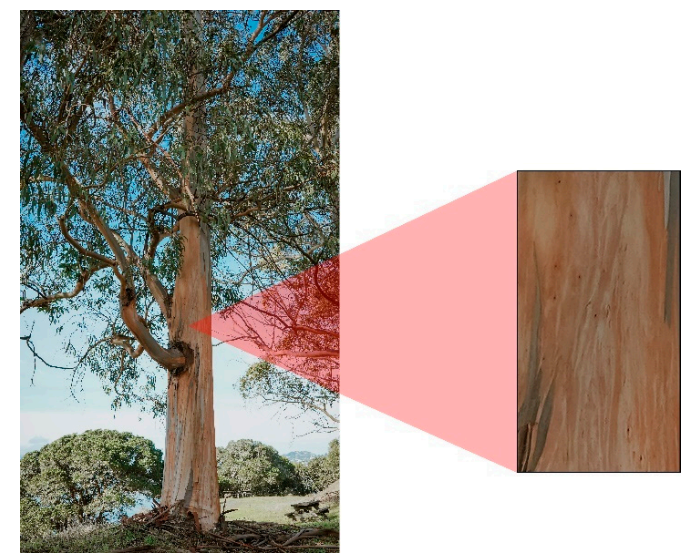

Figure 4. A tree trunk and tannins. Photo by Madeleine Maguire on Unsplash.

Hierarchical biological structures can be adopted to achieve multifunctionality in architecture through multi-scaled structures with multiple uses. For example, building systems at a larger hierarchical level can host one function and its material at a smaller scale can host another. This can be explained through the hierarchical components of a conventional façade (Figure 5). The external walls are at the large hierarchical scale as the enclosure of a building. The windows on the external walls are smaller and provide external views. The window openings are even smaller and provide ventilation. The glazing material of the windows is at the smallest scale, limiting solar gains or light. The combination of these components at difference scales creates a façade with multiple functions. Therefore, through using hierarchical scales in conventional systems with adaptability, it is possible to achieve multifunctionality in developing Bio-ABS.

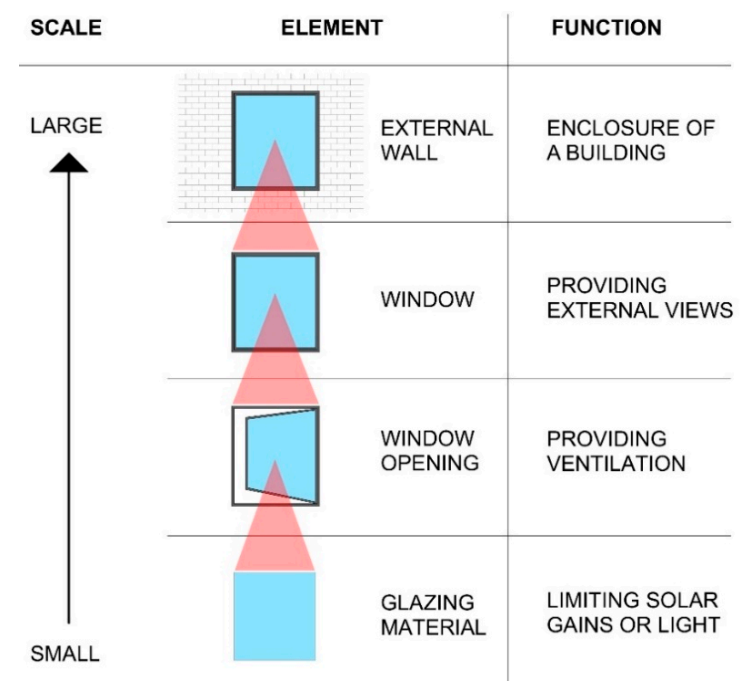

Figure 5. Hierarchical components on a conventional façade system at diverse scales including external walls, windows, window openings, and glazing material. 


\subsection{Achieving Multifunctionality through a Heterogeneous Geometric Differentiation}

Heterogeneity is characterized by a geometric differentiation of elements in multi-dimensional structures hosting different functions with various forms. [30]. Form and function are interrelated in nature. As such, it is almost impossible to separate one from another. Nature uses shape or form, rather than added material and energy, to meet functional requirements. This allows the organism to accomplish its needs using a minimum of resources [7]. In addition, chemical and structural heterogeneities play an important role in allowing local adjustments to be integrated.

There is often a functional reason behind a form in nature. For example, the carnivorous plant Venus flytrap (Dionaea muscipula) has a cup-shaped leaf that catches insects with a mechanism trapping prey in (Figure 6). There are small hairs or cilia that are sensory organelles on the leaves. A slight disturbance of the cilia by an insect triggers the collapse of the leaf. This mechanism, called snap instability, is achieved by its shape, and its kinetics has been studied by researchers and transferred into shading devices [30,71,72]. This shape of leaves helps the plant save energy when moving. It is important to note that as the function of the cilia is achieved by their form rather than their scale, this adaptation of the Venus flytrap is categorized under heterogeneity.

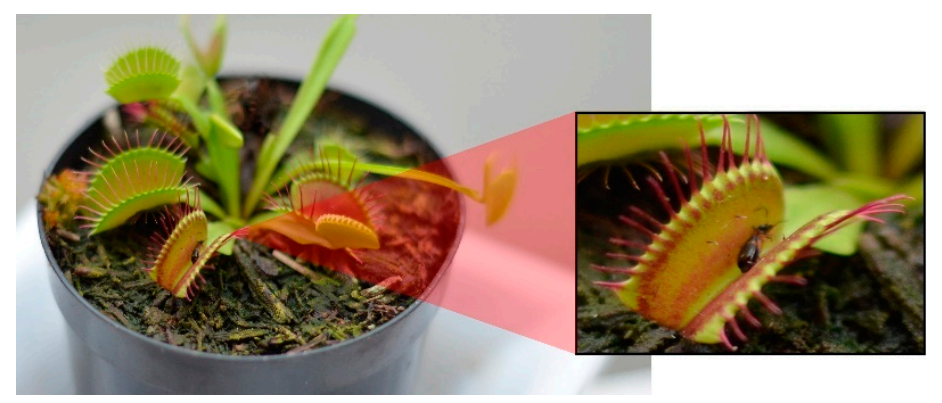

Figure 6. Venus flytrap (Dionaea muscipula) with its specialized cilia. Photo by Gabriel on Unsplash.

Heterogeneity can be adopted into architecture to achieve multifunctionality through having various morphologies. For example, different geometrical forms with diverse functions can be integrated in a system. This can be explained through the heterogeneous components of a conventional roof (Figure 7). The roof itself functions as the top covering of a building and the eaves are the edges of the roof which project beyond the side of a building. The eaves function as shadings and through their geometric differentiation from the roof, the system becomes multifunctional. Therefore, through combining the use of heterogeneous scales in conventional systems with adaptability, it is possible to achieve multifunctionality in developing Bio-ABS.

\subsection{Integrating Hierarchy and Heterogeneity Together}

Hierarchy through scales and heterogeneity through form in nature is developed in various complexities much further than the human eye can detect. In many cases, color and light transmittance or refraction is achieved by nano-scaled ridges, combining the principles of hierarchy and heterogeneity together. For instance, Morpho menelaus has transparent wings that are covered with micro scaled structures forming a textured pattern that diffuse light to achieve its color (Figure 8) [73]. This is a more efficient solution than having pigments, which in time can lose their properties or require energy to maintain. The wings function as means of flight bodies. The micro-scaled ridges add the wings an additional function, by having hierarchical elements. The wings being the larger-scale flight function and the ridges being the micro-scaled colorists therefore becoming heterogeneous [74,75]. 


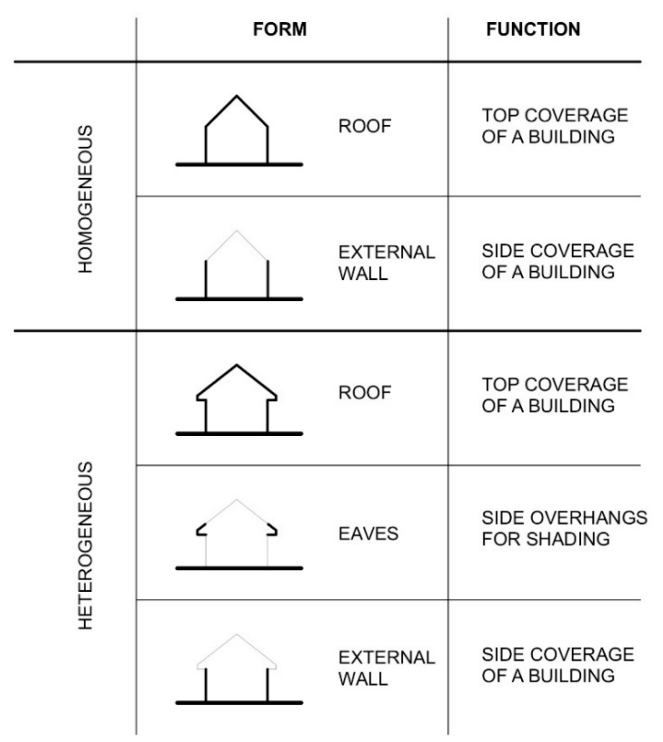

Figure 7. Heterogeneity in a conventional roof structure showing the heterogeneous forms of the roof and eaves.
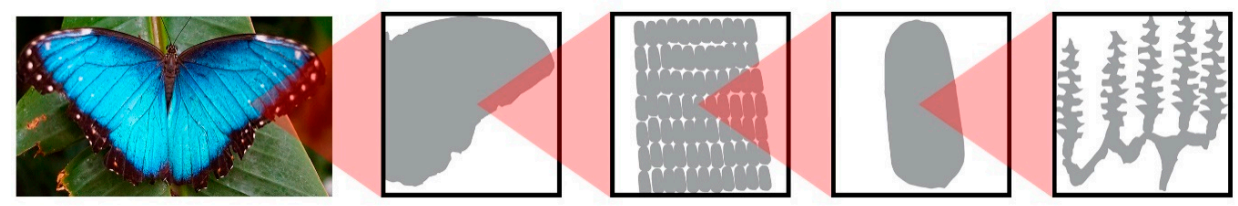

Figure 8. From left to right: Morpho Menelaus, its wings, micro-scaled structures forming a pattern over the wings, a single scale of Morpho Menelaus and a scale showing a few ridges giving color. Photo by Damon On Road on Unsplash.

Hierarchy and heterogeneity can be integrated together in achieving multifunctionality into architecture through differentiating functions at diverse scales and geometries. Similar to Morpho menelaus, a building can host a function on its different elements situated at diverse scales and on its functional surfaces differentiated by various geometries. For example, in conventional structures, this is achieved through having the hierarchy of system, component, material at diverse scales added together with surface structures as differentiated geometries. In this way, the traditional hierarchical parts of a building are formed. Then, the material properties of the specialized surfaces, i.e., nanostructured surfaces, are used at as small scale of the hierarchy. The material property adds heterogeneous forms in the hierarchy and therefore the whole system achieves multifunctionality through hierarchy and heterogeneity (Figure 9).

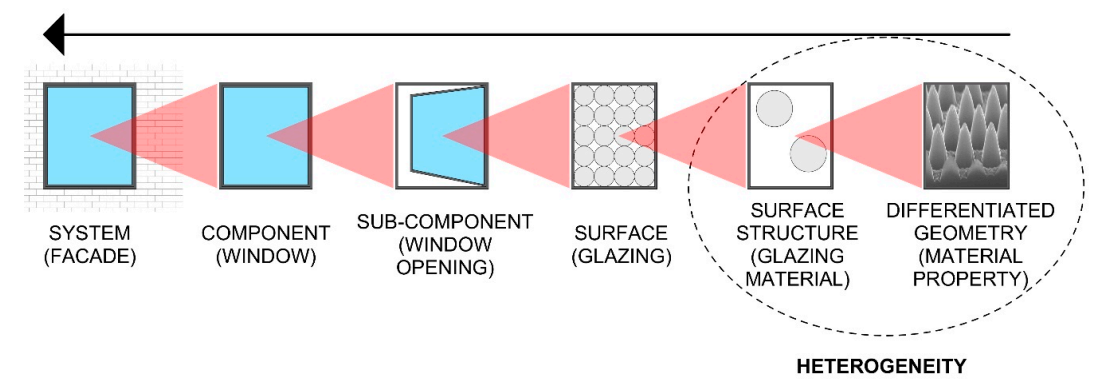

Figure 9. How buildings can achieve multifunctionality through integrating hierarchical building components with heterogeneous forms of material properties. 


\section{Methodology}

Several research methods are used in this study to achieve multifunctionality in Bio-ABS and to measure the benefit of implementing multifunctional Bio-ABS in buildings. These methods include the following.

(1) Literature review, synthesis, and comparative analysis of the existing biomimetic design frameworks.

(2) The case study of Echinocactus grusonii demonstrating a new biomimetic design framework to achieve multifunctionality in Bio-ABS.

(3) Building performance simulation of a digital base-case building model and the case study of a multifunctional Bio-ABS.

(4) Comparative analysis of the simulation results showing the improvement in thermal comfort multifunctional Bio-ABS offers.

The literature review, synthesis, and comparative analysis of the existing design frameworks aim at identifying the research gaps in developing Bio-ABS. In doing so, they draw attention to the limitations and successes of existing frameworks to develop Bio-ABS and outline whether multifunctionality is addressed. However, it is found that achieving multifunctionality with existing frameworks remains a gap, and to address this, a new framework is proposed. Therefore, as a method, framework is used in order to address the challenges faced in developing multifunctional Bio-ABS. Frameworks, in general, provide a holistic approach to address specific problems or challenges and they present the opportunity to be further improved as validated methodologies. To aid the framework developed, a preliminary database is created by mapping multifunctional mechanisms of organisms through a systematic classification as a growing source of multifunctional biological mechanisms. The new framework presents a process to develop multifunctional Bio-ABS using the database. Furthermore, a case study of Echinocactus grusonii (golden barrel cactus) implemented on a naturally ventilated educational building modeled digitally is developed through the demonstration of the new framework. This case study provides an example to use the database and framework to develop multifunctional Bio-ABS by translating the natural design principles of hierarchy and heterogeneity.

The digital base-case building is taken from the repository of U.S. Department of Energy that provides models for various building types. The building type selected is educational to investigate problems associated with comfort in schools, as most existing studies focus on office and commercial buildings [76-82]. Building performance simulation (BPS) of the digital base-case building targeting thermal comfort through the Adaptive Comfort Model applicable to naturally ventilated buildings is performed. The multifunctional Bio-ABS case study is implemented on the base-case building, replacing its windows. The software used to model and simulate the base-case building and case study is EnergyPlus. This was chosen as it provides a flexible input-output interface to model multifunctional facades using the built-in tool Energy Management System (EMS). EMS has customizable input objects that is suitable to model adaptive facades $[79,83,84]$. A comparative analysis for the BPS results of the base-case building and Bio-ABS case study is made to draw out the improvements in comfort multifunctional Bio-ABS offer over conventional buildings.

\section{Classification of Biological Mechanisms for Multifunctionality Bio-ABS}

This section presents a database mapping multifunctional properties of organisms. To do so, we classified biological mechanisms in terms of multifunctionality. The classification is comprised of three layers in Table 2:

(1) Named species presenting the biological system,

(2) adaptability presenting the type of biological adaptations, and

(3) multifunctionality presenting biological functional strategies divided into hierarchy and heterogeneity sub-categories. 
Table 2. The classification parameters of biological mechanisms for achieving multifunctionality in developing Bio-ABS.

\begin{tabular}{|c|c|c|c|}
\hline Layer & Scope & Parameters & \\
\hline \multirow{2}{*}{ 1. Species } & Biological system & - & \\
\hline & Scientific name & - & \\
\hline \multirow{4}{*}{ 2. Adaptability } & \multirow{2}{*}{ Stimulus } & Physical & \\
\hline & & Chemical & \\
\hline & \multirow{2}{*}{ Process } & Dynamic & \\
\hline & & Static & \\
\hline \multirow{12}{*}{ 3. Multifunctionality } & \multirow{5}{*}{$\begin{array}{l}\text { Environmental } \\
\text { factor }\end{array}$} & Heat & \\
\hline & & Light & \\
\hline & & Air & \\
\hline & & Water & \\
\hline & & Energy & \\
\hline & \multirow{4}{*}{ Function } & Maintain & \\
\hline & & Exchange & \\
\hline & & Gain & \\
\hline & & Lose & \\
\hline & \multirow{3}{*}{ Mechanism } & Biological mechanism & \\
\hline & & Functional strategy & \\
\hline & & Performance measure & \\
\hline \multirow{5}{*}{ 3.a. Hierarchy } & \multirow{5}{*}{$\begin{array}{l}\text { Biological } \\
\text { organization scale }\end{array}$} & Pre-cellular & Atom, molecule \\
\hline & & Sub-cellular & Organelle \\
\hline & & Cellular & Cell \\
\hline & & Multicellular & Tissue, organ, organism \\
\hline & & Ecological & Ecosystem, biome \\
\hline \multirow{3}{*}{ 3.b. Heterogeneity } & \multirow{3}{*}{$\begin{array}{l}\text { Adaptation type } \\
\text { and level }\end{array}$} & Morphological & $\begin{array}{l}\text { Form } \\
\text { Structure } \\
\text { Texture }\end{array}$ \\
\hline & & Physiological & $\begin{array}{l}\text { Chemical response } \\
\text { Trait }\end{array}$ \\
\hline & & Behavioral & $\begin{array}{l}\text { Kinetic response } \\
\text { Tropism } \\
\text { Nastic movement }\end{array}$ \\
\hline
\end{tabular}

\subsection{Species and Adaptability Layers}

The species layer comprises the name of the biological system and its scientific name. The stimulus presents the set of triggers biological mechanisms respond to, defined as physical and chemical. Physical stimuli refer to the internal and external environmental triggers including the changes in environmental factors. These range anywhere from heat, light, to water content. Chemical stimuli refer to physiological triggers detected by a receptor. Chemical stimuli promote internal responses including changes in $\mathrm{pH}$. Adaptive features of living systems occur as either dynamic or static processes, demonstrating the kinds of changes. A dynamic process relates to motion such as behavioral adaptations. In static processes, no change is present. Examples include nanostructured textural features of living systems such as waxy surface structures of water lily (Nymphaeaceae) and lotus flower (Nelumbo nucifera) keeping them dry off the water [85,86].

\subsection{Multifunctionality Layer}

\subsubsection{Environmental Factor, Function, and Mechanism}

The environmental factor refers to climatic variables that biological mechanisms control, categorized as heat, light, air, water, and energy. For example, heat includes surface or body temperature (referred as thermoregulation in living systems), absorption, and dissipation of heat. Light 
is related to the impact and management of solar irradiance and radiation including light intensity, reflection, refraction, and absorption. Air is related to air and gas management including oxygen intake, air flow and gas exchange. Water is related to water content in the body or in the air or the surrounding environment of a living system including absorbing the moisture from the air, diffusion of moisture, and waxy surfaces to hold moisture over the surface. Energy is related to the generation and conservation of energy.

The function describes the control that biological mechanisms host over the environmental factors. These include gain, lose, maintain, and exchange. Gain refers to absorbing, warming up, and enhancing; describing an increase. Lose is the opposite of gain, referring to reflecting, refracting, cooling down, and evaporation; describing a decrease. Maintain refers to managing, intensifying, and thermal regulation; describing a certain variable is remained as a constant. Last, exchange refers to absorbing, taking, and filtering; describing the simultaneous emergence of gain and lose.

The biological mechanism is the driving force of the classification that presents the functional characteristics of living systems. Examples of biological mechanisms include self-shading areoles and spines of cacti, and shrinking and swelling stem structures of succulents [87]. A functional strategy refers to the performative role played by an organism's adaptations. Examples include maximizing the amount of light reflected, passive ventilation through altering air pressure and thermoregulation through retaining absorbed heat [88].

\subsubsection{Hierarchy}

Biological organization is the hierarchical order of biological systems, extending from atoms to biospheres Each level in the hierarchy represents an increase in organizational complexity, with each 'object' being composed of the previous level's basic unit. The basic principle behind the organization is the concept of emergence: the properties found at a hierarchical level are not present and irrelevant at the lower levels. In most simple terms, the biological organization level relates to the level at which the biological mechanism is part of a living system (Figure 10). Organisms achieve multifunctionality through having multiple functions located at their hierarchical multi-level biological structures. To promote biomimetic strategies with multiple functions, the biological levels of those biological mechanisms are identified. This categorization aims at presenting how diverse functions are combined in living systems and gives clues to creating corresponding technical systems. For instance, if a biological mechanism is situated at a cell level, it can be combined with another mechanisms that is located at a different level such as organ or organism [34].

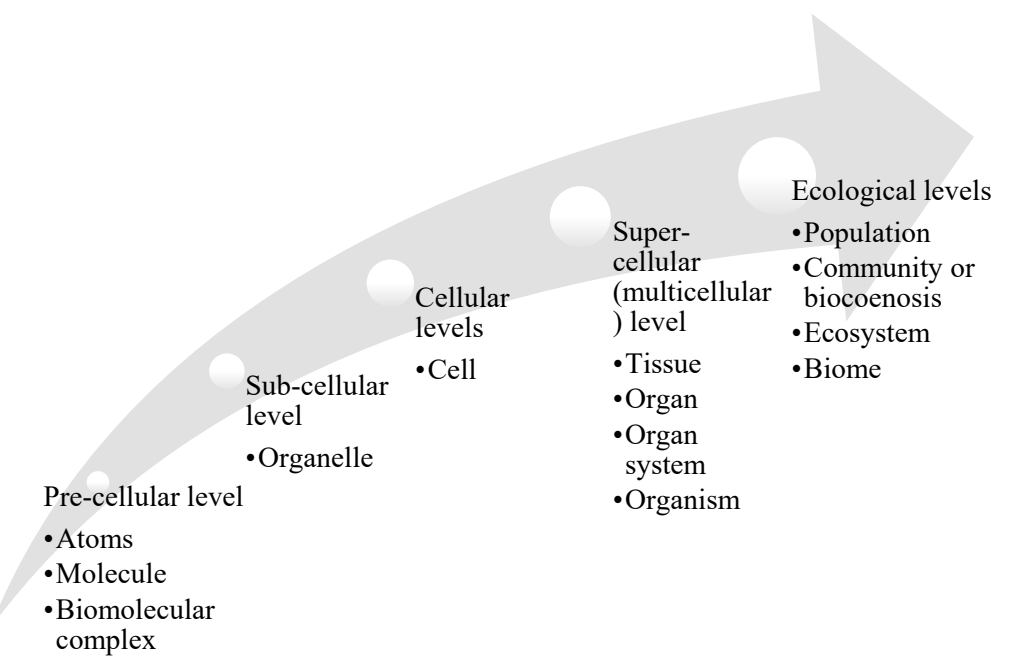

Figure 10. Biological organization scales. 


\subsubsection{Heterogeneity}

Morphological adaptions occur through the changes in the morphology of an organism. Examples include the movement of wooden-like scales of the big pine cone (Pinus coultieri) when the water content in the air fluctuates to manage moisture. In morphological adaptations, form is related to the size or shape of an organism. Structure relates to a structure of an organism, as biological spatial and structural material-systems. Examples include shell structures such as the sea urchin (Echnoidea) and sand dollar (Clypeasteroida). Texture results from segmentation trends of biological surfaces of an organism. Examples include thorny fruit trees such as durian, to provide self-shading with scale structures [89].

Physiological adaptations occur through internal changes of an organism. Examples include Crassulacean Acid Metabolism in cacti, a carbon fixation pathway where the stomata remain shut during the day to reduce evapotranspiration, while open at night to collect carbon dioxide to diffuse into cells. In physiological adaptations, trait relates to phenotypic characteristics of an organism as results of the evolutionary processes. Examples include the eye color as a character of humans, while blue, brown, and green colors are traits. Chemical processes result from internal chemical processes of an organism. Examples include the physiology of stomatal openings facilitating gas exchange through a pair of specialized guard cells [61].

Behavioral adaptations are changes in the behavior of an organism, mostly resulting in movement. Kinetic response is the movement in living systems other than plants. Examples include kangaroos (Macropodidae) licking their paws for evaporation and crouching into smaller position for decreased heat gain. Nastic movement is plants' response to an external stimulus (i.e., temperature, light, and chemicals) independent from its direction. Examples include thermonasty of tulips (Tulipa), closing and openings according to the changes in temperature and thigmonasty of wood sorrels (Oxalidaceae) as a response to vibration. Tropism is plants' response to an external stimulus (i.e., oxygen, sun, and humidity) depending on its direction, as opposed to nastic movement. Examples include hydrotropism such as tomato roots, the tendency to grow towards higher moisture content (Figure 11).
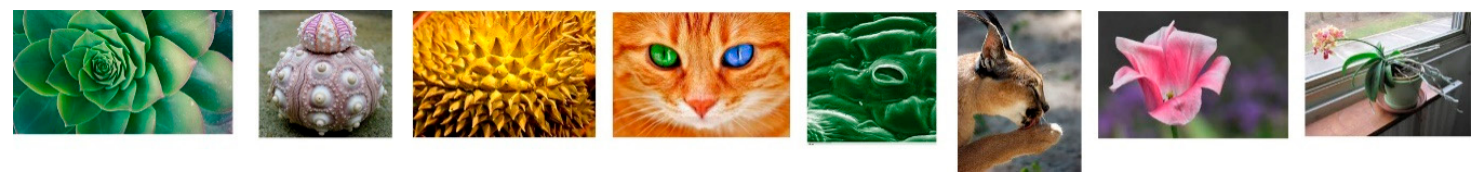

Figure 11. Examples of adaptations or characteristics from left to right; in morphology-succulent's form, sea urchin's structure, durian's thorns; in physiology-eye color trait, photosynthesis of stoma; in behavior-licking paws for evapotranspiration, thermonasty, and phototropism.

\subsection{Examples of Classified Biological Systems}

In an attempt to demonstrate this systematic classification, we mapped biological systems in a 'preliminary database' for achieving multifunctionality in biomimetic designs (Table 3). The biological systems are organized to present their multifunctional properties, giving insight to their hierarchical or heterogeneous structures. The classification and the database are to be used as part of the framework proposed in this paper further. The table presented below provides the information on an extract (sixteen entries) from the database. The database in its current format consists of 43 entries and it is yet to be complete as a growing source of multifunctional mechanisms of biological systems. 
Table 3. A preliminary mapping of several biological systems through the systematic classification. (in stimulus P: physical, C: chemical; in process D: dynamic, S: static; in biological organization scales O: organ, T: tissue, C: cell; in adaptation types M: morphological, P: physiological, B: behavioral; in adaptation levels F: form, S: structure, TEX: texture, CR: chemical response, KR: kinetic response, NM: nastic movement, TRO: tropism; N/A: Not available). Information is gathered from various sources $[6,8,12,13,50,89-110]$.

\begin{tabular}{|c|c|c|c|c|c|c|c|}
\hline Species & Adapta & bility & & Multifu & ctionality & & \\
\hline Biological System & Stimulus & Process & Function & Mechanism & $\begin{array}{l}\text { Biological } \\
\text { Organization } \\
\text { Scale } \\
\text { (Hierarchy) }\end{array}$ & $\begin{array}{l}\text { Adaptation } \\
\text { Level } \\
\text { (Heterogeneity) }\end{array}$ & $\begin{array}{c}\text { Adaptation } \\
\text { Type } \\
\text { (Heterogeneity) }\end{array}$ \\
\hline $\begin{array}{l}\text { Australian Banksia } \\
\text { Seeds (Banksia } \\
\text { attenuata) }\end{array}$ & $\mathrm{P}$ & $\mathrm{D}$ & $\begin{array}{l}\text { Maintain/Exchange } \\
\text { light and heat }\end{array}$ & $\begin{array}{l}\text { Managing UV radiation, } \\
\text { high ambient summer } \\
\text { temperatures by crack } \\
\text { openings }\end{array}$ & 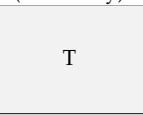 & $P$ & Trait \\
\hline \multirow{2}{*}{ Stone Plant (Lithops) } & N/A & S & $\begin{array}{l}\text { Gain/Maintain/Lose } \\
\text { light }\end{array}$ & $\begin{array}{l}\text { Translucent and colored } \\
\text { patterned epidermal } \\
\text { windows on the leaves }\end{array}$ & $\mathrm{T}$ & $\mathrm{P}$ & Trait \\
\hline & $P$ & $\mathrm{D}$ & $\begin{array}{c}\text { Gain/Maintain } \\
\text { waterLoose/Maintain } \\
\text { heat }\end{array}$ & $\begin{array}{l}\text { Shrinking and swelling } \\
\text { leaves }\end{array}$ & $\mathrm{O}$ & M & $\mathrm{F}$ \\
\hline $\begin{array}{l}\text { Saharan Silver Ant } \\
\text { (Cataglyphis } \\
\text { bombycina) }\end{array}$ & $P$ & $\mathrm{D}$ & $\begin{array}{l}\text { Maintain/Lose light } \\
\text { and heat }\end{array}$ & $\begin{array}{c}\text { Triangular reflective hair } \\
\text { and grooves reducing heat } \\
\text { absorption, reflection, and } \\
\text { refraction }\end{array}$ & $\mathrm{T}$ & M & TEX \\
\hline \multirow{2}{*}{$\begin{array}{l}\text { Desert Snail } \\
\text { (Sphincterochila } \\
\text { boisseri) }\end{array}$} & N/A & S & $\begin{array}{l}\text { Maintain/Lose light } \\
\text { and heat }\end{array}$ & $\begin{array}{l}\text { Highly reflective shell } \\
\text { surface allowing } \\
\text { conduction }\end{array}$ & $\mathrm{O}$ & $P$ & Trait \\
\hline & $\mathrm{P}$ & $\mathrm{D}$ & Maintain heat & $\begin{array}{l}\text { Layer of insulating air } \\
\text { cushion }\end{array}$ & $\mathrm{O}$ & B & $\mathrm{KR}$ \\
\hline $\begin{array}{c}\text { Glass Snail } \\
\text { (Oxychilus } \\
\text { draparnaudi) }\end{array}$ & N/A & S & $\begin{array}{l}\text { Maintain/Lose light } \\
\text { and heat }\end{array}$ & $\begin{array}{l}\text { Glossy translucent shell } \\
\text { called glass house allowing } \\
\text { reflectance }\end{array}$ & $\mathrm{O}$ & $P$ & Trait \\
\hline \multirow{2}{*}{$\begin{array}{l}\text { Butterfly-Menelaus } \\
\text { Blue Butterfly } \\
\text { (Morpho menelaus) }\end{array}$} & $\mathrm{P}$ & $\mathrm{D}$ & $\begin{array}{l}\text { Maintain light and } \\
\text { heat }\end{array}$ & $\begin{array}{l}\text { Wings scale structures } \\
\text { allowing structural } \\
\text { coloration }\end{array}$ & $\mathrm{O}$ & M & TEX \\
\hline & N/A & S & Gain energy & $\begin{array}{l}\text { Microscopically thin layers } \\
\text { of film (chitin) on wings } \\
\text { absorbing energy/infrared } \\
\text { light }\end{array}$ & $\mathrm{O}$ & $\mathrm{P}$ & Trait \\
\hline \multirow[t]{2}{*}{ Bark of Trees } & N/A & S & $\begin{array}{l}\text { Maintain light and } \\
\text { heat }\end{array}$ & $\begin{array}{c}\text { Tannins on the bark surface } \\
\text { managing optical } \\
\text { properties through } \\
\text { nanostructures }\end{array}$ & $\mathrm{T}$ & $\mathrm{P}$ & Trait \\
\hline & N/A & S & $\begin{array}{l}\text { Maintain air, light, } \\
\text { and heat } \\
\text { Lose light and heat }\end{array}$ & $\begin{array}{l}\text { Rough bark surface } \\
\text { producing shadowed areas } \\
\text { amongst the illuminated } \\
\text { ones, stimulating } \\
\text { convection of air }\end{array}$ & $\mathrm{T}$ & M & TEX \\
\hline \multirow[t]{2}{*}{$\begin{array}{l}\text { Cactus-Barrel cactus } \\
\text { (Echinocatus } \\
\text { grusonii) }\end{array}$} & $\mathrm{P}$ & $\mathrm{D}$ & $\begin{array}{l}\text { Maintain water } \\
\text { Lose light and heat }\end{array}$ & $\begin{array}{l}\text { Swelling and shrinking } \\
\text { cortex achieving high } \\
\text { surface to volume ratio } \\
\text { through the ribs structured } \\
\text { stem }\end{array}$ & $\mathrm{O}$ & M & $\mathrm{F}$ \\
\hline & N/A & S & Lose light and heat & $\begin{array}{l}\text { Self-shading areoles and } \\
\text { spines over the cortex } \\
\text { epidermal layer }\end{array}$ & $\mathrm{T}$ & M & TEX \\
\hline Stoma & C & $\mathrm{D}$ & $\begin{array}{l}\text { Exchange heat, air, } \\
\text { and light }\end{array}$ & $\begin{array}{l}\text { Microscopic and permeable } \\
\text { stomatal openings }\end{array}$ & C & $\mathrm{P}$ & CR \\
\hline \multirow[b]{2}{*}{ Camel (Camelus) } & $\mathrm{P}$ & $\mathrm{D}$ & $\begin{array}{l}\text { Maintain/Exchange } \\
\text { light and water }\end{array}$ & $\begin{array}{l}\text { Open/closed configurations } \\
\text { of the shell }\end{array}$ & $\mathrm{T}$ & B & $\mathrm{KR}$ \\
\hline & $\mathrm{P}$ & $\mathrm{D}$ & $\begin{array}{l}\text { Maintain/Lose heat } \\
\text { Exchange water }\end{array}$ & $\begin{array}{c}\text { Hygroscopic nasal passages } \\
\text { cooling exhaled air during } \\
\text { night and extracting water } \\
\text { vapor from air }\end{array}$ & $\mathrm{T}$ & $\mathrm{P}$ & Trait \\
\hline Spurge (Euphorbias) & N/A & S & $\begin{array}{c}\text { Maintain heat and } \\
\text { water } \\
\text { Lose heat } \\
\text { Gain water }\end{array}$ & $\begin{array}{l}\text { Managing water content } \\
\text { and heat through waxy } \\
\text { surface covering the stem }\end{array}$ & $\mathrm{T}$ & $\mathrm{P}$ & Trait \\
\hline $\begin{array}{l}\text { Rhododendron } \\
\text { Leaves }\end{array}$ & $\mathrm{P}$ & $\mathrm{D}$ & $\begin{array}{l}\text { Maintain/Gain heat } \\
\text { Maintain water } \\
\text { Lose light and heat }\end{array}$ & $\begin{array}{l}\text { Curling movement of the } \\
\text { leaves triggered by heat } \\
\text { allowing the reduction of } \\
\text { the total quantity of light } \\
\text { absorbed by the leaf }\end{array}$ & $\mathrm{O}$ & B & TRO \\
\hline \multirow[t]{2}{*}{ Fern Leaves } & N/A & S & $\begin{array}{l}\text { Maintain/Lose light } \\
\text { Gain energy }\end{array}$ & $\begin{array}{l}\text { Special structures } \\
\text { absorbing solar radiation, } \\
\text { and managing light by } \\
\text { reflection and refraction }\end{array}$ & C & $\mathrm{P}$ & CR \\
\hline & C & $\mathrm{D}$ & $\begin{array}{l}\text { Exchange air and } \\
\text { water }\end{array}$ & $\begin{array}{l}\text { Permeability of outer leaf } \\
\text { surface allowing diffusion }\end{array}$ & C & $\mathrm{P}$ & CR \\
\hline
\end{tabular}


Table 3. Cont.

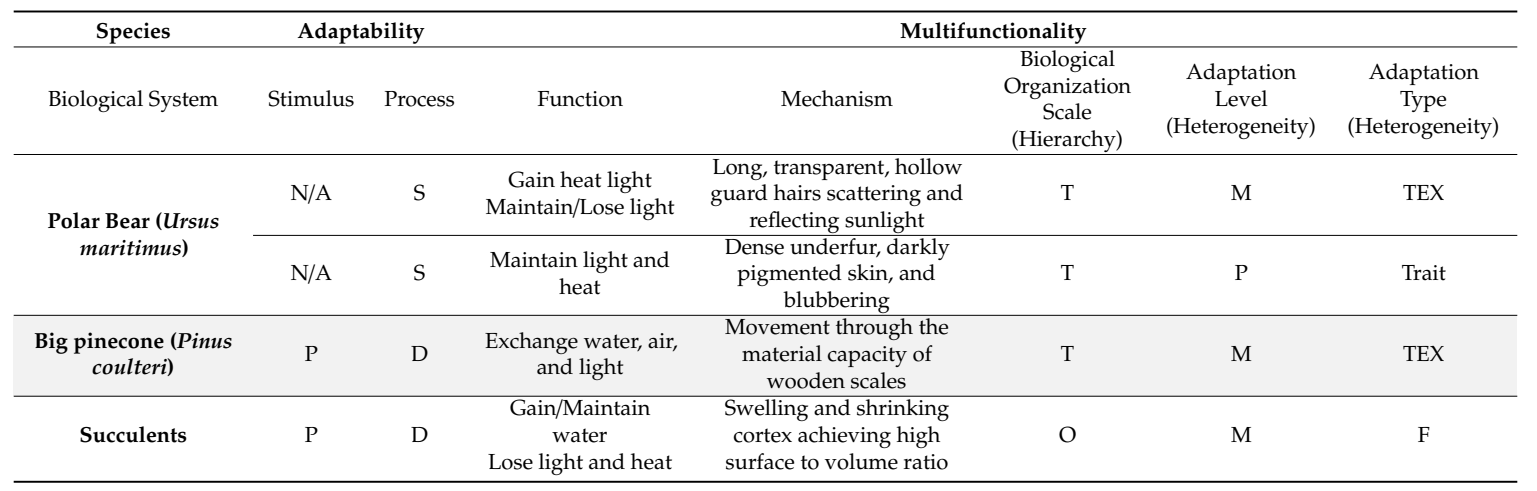

\section{Developing a Framework to Achieve Multifunctionality in Bio-ABS}

To achieve multifunctionality in Bio-ABS, a framework called the 'Multi-Biomechanism Approach' is proposed. This is a top-down approach focusing on technical problems to be solved through biological inspiration. It is comprised of four stages (Figure 12):

(1) Identifying a technical problem.

(2) Selecting a biological solution.

(3) Achieving multifunctionality.

(4) Developing a biomimetic strategy.

Each stage is comprised of sub-stages, which are facilitated by the classification of multifunctional biological mechanisms as outlined in Table 3. Stage one is comprised of the two sub-stages of selecting a base-case scenario that includes a location, the climate, and the performance analysis of that base-case scenario and identifying functional requirements to improve the performance. Stage two is comprised of matching functional requirements of the base-case scenario with a corresponding biological system found in the database. A suitable biological system with multifunctional properties is selected to serve as a case study. Stage three is comprised of outlining the properties of the chosen biological system as hierarchical and heterogeneous structures to achieve multifunctionality. This includes the identification of biological organization scales, adaptation levels and types of the chosen biological mechanisms. Stage four is comprised of designing a Bio-ABS with functions at diverse scales and with different geometries. In doing so, several configurations of the Bio-ABS are produced, and actuation mechanisms are presented that deliver climate-adaptability. Further details on how to perform the stages of the framework are described thoroughly in the following sections of this paper with a case study demonstrating its use.

\subsection{Stage 1: Identifying Technical Problems}

The identification of technical problems involves identifying optical, acoustic, and energetic controls over a base-case scenario. This is achieved through selecting location, climate, and a base-case building to identify functional requirements. A performance analysis of the base-case is proposed to define the functions required, such as through building performance simulation. The functions defined are suggested to use a simplified language as maintain, exchange, lose, and gain; of the environmental factors as heat, light, air, water, and energy. For instance, results of a performance analysis may suggest that cooling energy loads are relatively high. This indicates heat regulation through the function lose can be investigated as thermoregulation in organisms. 


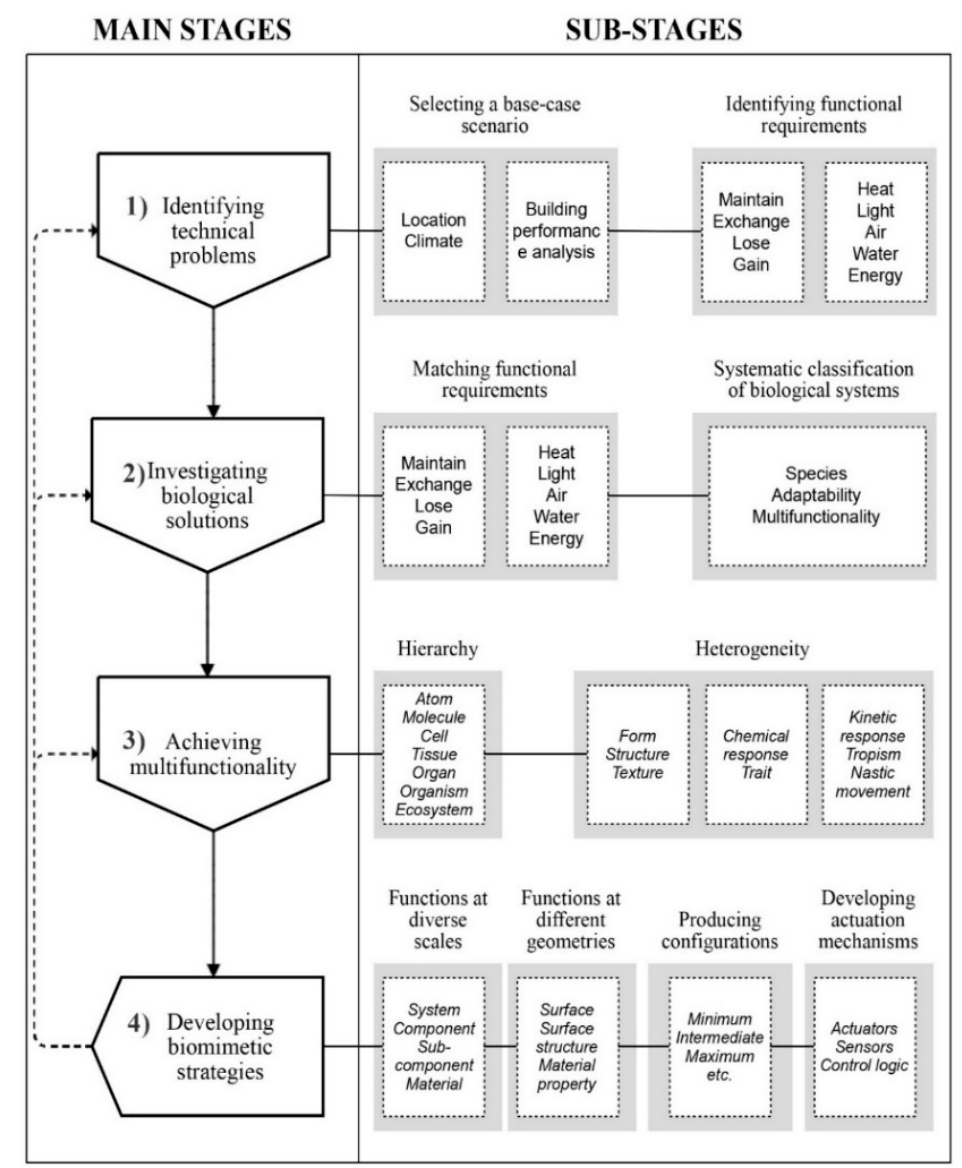

Figure 12. The multi-biomechanism approach and its stages. (1) Identifying technical problems, (2) investigating biological solutions, (3) achieving multifunctionality, and (4) developing biomimetic strategies.

\subsection{Stage 2: Investigating Biological Solutions}

The second stage is to find solutions in nature that respond to similar problems as identified in Stage 1. This stage is comprised of matching functional requirements, investigating corresponding biological mechanisms, and selecting biological models. To match functional requirements between the base-case building and nature, the same terms for functions (maintain, exchange, lose, and gain) and environmental factors (heat, light, air, water, and energy) are suggested to be used.

\subsection{Stage 3: Achieving Multifunctionality}

The third stage is to achieve multifunctionality through selecting multiple biological mechanisms, situating mechanisms at diverse scales, and developing actuation mechanisms. Multiple biological mechanisms whether they belong to the same biological model or not, should be selected to develop a multifunctional system. The significance in this stage is to employ hierarchy or heterogeneity as drivers. This means either situating the selected mechanisms at diverse scales, or selecting diverse types of morphological, physiological, or behavioral adaptations in a heterogeneous structure.

\subsection{Stage 4: Developing Biomimetic Strategies}

The final stage is developing biomimetic strategies, comprised of developing a façade design, selecting smart materials as actuators, and producing configurations. For example, the Stone Plant (Lithops) maintains light levels through its translucent and colored structures. This mechanism can be transferred as a texture changing its light transmittance. Moreover, the opening movement of stomata 
is a dynamic process that relates to a motion happening at a cellular scale. These mechanisms can be combined together and translated into a potential Bio-ABS design.

\section{The Case Study of Echinocactus grusonii}

This section describes the case study of a multifunctional Bio-ABS following the four stages of the Multi-Biomechanism Approach. The case study of Echinocactus grusonii is implemented on a digital reference building through translating its multifunctional properties using the concepts of hierarchy and heterogeneity. Further on, building performance simulation of the base-case building before and after implementing the multifunctional Bio-ABS case study is conducted. A comparative analysis of the simulation results is presented showing the performance improvements.

\subsection{Stage 1: Identifying Technical Problems}

To determine the technical problems in a base-case scenario, a climatic context with a location and reference building must be selected. A base-case scenario is selected in Sydney, Australia, with humid warm temperate climate characterized by warm summers and cool winters [111]. A digital reference educational building from the United States Department of Energy repository was selected to serve as a base-case model [112]. The building type selected is educational to investigate problems associated with comfort in schools, as most existing studies focus on offices and commercial buildings [78-84]. The reference building was located in Atlanta, USA, as Atlanta shows climatic similarity to Sydney. It is anticipated that the geometry of the reference building is suitable for a similar climate.

The reference building is simulated using the software EnergyPlus, in which the building was already modeled. The simulation results are presented further in this section in '7.5. Comparative analysis of environmental performance evaluation'. As results of the simulation, technical problems in the building are identified. The technical problems are defined as excessive heat, need for cooling, and high solar gains. The problems are revised using the simplified language specified in the framework. The translation of excessive heat is described as to lose and maintain heat, the need for cooling as to gain and exchange air, and high solar gains as to lose and maintain light (Table 4).

Table 4. Defining technical problems as functional requirements.

\begin{tabular}{cc}
\hline Technical Problem & Functional Requirement \\
\hline Excessive heat & Lose/maintain heat \\
Need for cooling & Gain/exchange air \\
High solar gains & Lose/maintain light \\
\hline
\end{tabular}

\subsection{Stage 2: Investigating Biological Solutions}

A search for the functional requirements resulted with several biological systems including Echinocactus grusonii, Pinus coultieri, and succulents. The search for three different functions in the database is performed to investigate various biological mechanisms. The first function (air regulation) results with 11 entries including Echinocactus grusonii, big pine cone (Pinus coulteri), stomata, succulents, and barnacles (Chthamalus stellatus). The second function (light regulation) results with 33 entries including Echinocactus grusonii, Pinus coulteri, succulents, Mimosa pudica, Lithops, and Saharan silver ant (Cataglyphis bombycina). The third function (heat regulation) results with 43 entries including Echinocactus grusonii, Pinus coulteri, stomata, succulents, Mimosa pudica, Lithops, and Cataglyphis bombycina. The functions are as listed below.

(1) Function IN ('Exchange', 'Gain') AND 'Environmental Factor' = 'Air',

(2) Function IN ('Lose', 'Maintain') AND ‘Environmental Factor' = 'Light'

(3) Function IN ('Lose', 'Maintain') AND ‘Environmental Factor' = 'Heat' 
As results of the search, three biological systems are found in the intersection with corresponding strategies. These are Echinocactus grusonii, Pinus coulteri, and succulents. In addition, cacti and succulents have their stomatal openings situated on the external layer of their epidermis, which forms a hierarchical adaptation at a smaller scale of the stem. In Pinus coulter, stomata are situated on the leaves that are part of the tree instead. Pinus coulteri exchanges water, air, and light by a response to moisture. It presents a movement through the movement by the wooden scales, which results in one type of morphological adaptation as a texture. Succulents gain and maintain water; lose light and heat through swelling and shrinking cortex, similar to cacti. However, this results in one type of morphological adaptation as a form of an organ. However, Echinocactus grusonii not only achieves what succulents do through a similar adaptation with a different form, and have their stomata on their stem different to pine cone, but it also loses light and heat through its self-shading areoles and spines. This additional morphological adaptation is a texture. Therefore, Echinocactus grusonii is chosen among the three biological systems as it provides two morphological adaptations at diverse hierarchical scales (organ and tissue) and has different textural heterogeneous structures (areoles and spines).

Some of the adaptations of Echinocactus grusonii involve the swelling and shrinking movement and high surface-to-volume ratio of the stem, self-shading areoles, and spines over the cortex as a morphology; and the microscopic stomatal openings as physiological mechanisms (Table 5). The cactus stem swells, shrinks, and maintains a high surface-to-volume ratio, through the unique ribs structure. Studies show that Echinocactus grusonii can expand up to $54 \%$ of its initial surface area $[105,109]$. At the shrunk state, self-shaded areas in between the ribs help cool the surface temperatures down. The surface-to-volume ratio increases as the cactus gets larger, losing heat and light. There are areoles on the cortex out of which grow spines, self-shading and creating cooler microclimate. Studies show that Echinocactus grusonii can achieve up to a difference of $17^{\circ} \mathrm{C}$ in winter and $25^{\circ} \mathrm{C}$ in summer between the surface and air temperatures through these morphological adaptations [64]. Stomata are microscopic pores on leaves to transpire water and exchange air and heat, but in cacti they are placed directly on the stem. Echinocactus grusonii has 15 to 70 stomata per square millimeter [103].

Table 5. Echinocactus grusonii and its properties. (in stimulus P: physical, C: chemical; in process D: dynamic, S: static; in biological organization scales O: organ, T: tissue, C: cell; in adaptation types M: morphological, P: physiological; in adaptation levels F: form, TEX: texture, CR: chemical response; N/A: Not available).

\begin{tabular}{|c|c|c|c|c|c|c|c|}
\hline Species & Adapta & bility & & Multifu & ctionality & & \\
\hline Biological System & Stimulus & Process & Function & Mechanism & $\begin{array}{c}\text { Biological } \\
\text { Organization } \\
\text { Scale } \\
\text { (Hierarchy) }\end{array}$ & $\begin{array}{c}\text { Adaptation } \\
\text { Type } \\
\text { (Heterogeneity) }\end{array}$ & $\begin{array}{c}\text { Adaptation } \\
\text { Level } \\
\text { (Heterogeneity) }\end{array}$ \\
\hline \multirow[t]{2}{*}{$\begin{array}{l}\text { Cactus-Barrel cactus } \\
\text { (Echinocatus } \\
\text { grusonii) }\end{array}$} & $\mathrm{P}$ & $\mathrm{D}$ & $\begin{array}{l}\text { Maintain water } \\
\text { Lose light and heat }\end{array}$ & $\begin{array}{l}\text { Swelling and shrinking } \\
\text { cortex achieving high } \\
\text { surface to volume ratio } \\
\text { through the ribs structured } \\
\text { stem }\end{array}$ & $\mathrm{O}$ & M & $\mathrm{F}$ \\
\hline & N/A & S & Lose light and heat & $\begin{array}{l}\text { Self-shading areoles and } \\
\text { spines over the cortex } \\
\text { epidermal layer }\end{array}$ & $\mathrm{T}$ & M & TEX \\
\hline Stoma & C & $\mathrm{D}$ & $\begin{array}{l}\text { Exchange heat, air, } \\
\text { and light }\end{array}$ & $\begin{array}{l}\text { Microscopic and permeable } \\
\text { stomatal openings }\end{array}$ & C & $\mathrm{P}$ & CR \\
\hline
\end{tabular}

\subsection{Stage 3: Achieving Multifunctionality}

The mechanisms of Echinocactus grusonii are situated at diverse scales of biological organization and differentiated morphologies. For example, the swelling and shrinking cortex is a morphological adaptation that hosts the function of losing heat by the differentiated form of the ribs' structure covering the cortex over the spherical stem. This is an example of heterogeneity in nature. Moreover, the self-shading areoles and spines are morphological adaptations as a differentiated form of texture over the ribs presenting heterogeneity. On the other hand, the microscopic stomatal openings operate as physiological adaptation. All three adaptations are situated at different scales of biological organization: 
stomatal openings at the cellular level and areoles and spines at the tissue and ribs structured cortex at the organ levels. This shows an example for hierarchy in nature. Therefore, the translation of the cortex can be activated by heat and light. Being at the largest level among the mechanisms, it may be transferred into a larger spatial scale. The translation of the stomatal openings may work in conjunction with the ribbed stem, regulating heat and light. This mechanism can be transferred as openings at a medium-level spatial scale for air intake, activated by temperature. The areoles and spines regulate light through creating a texture over the cortex, activated by light. This mechanism can be translated at a smaller scale such as sub-component (Figure 13).

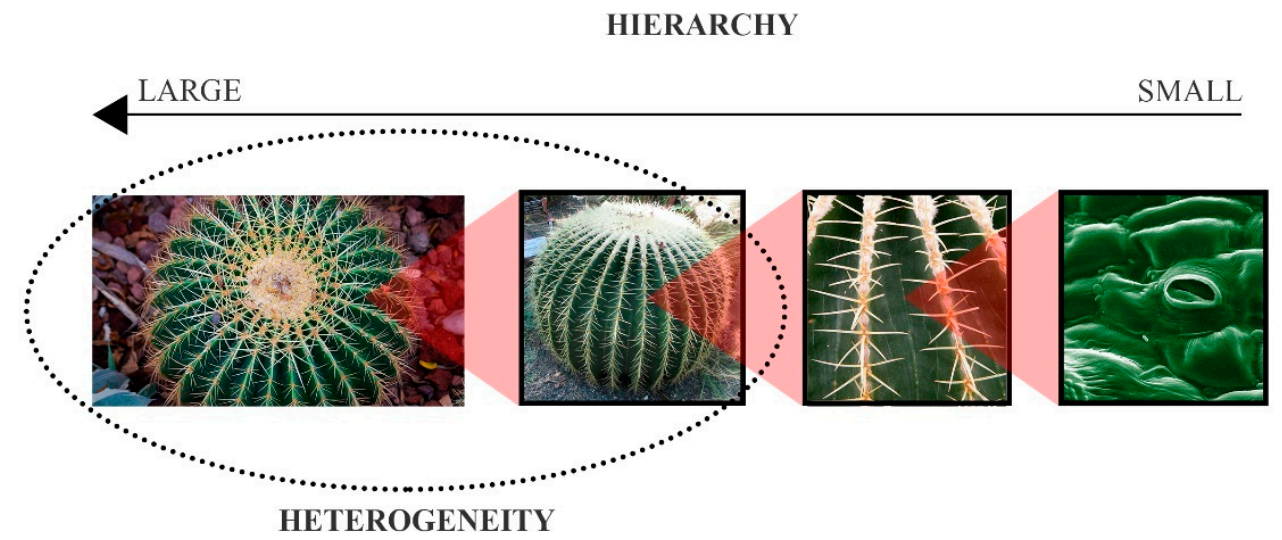

Figure 13. Multifunctionality through hierarchy and heterogeneity in Echinocactus grusonii.

\subsection{Stage 4: Developing Biomimetic Strategies}

The selected mechanisms of Echinocactus grusonii are translated into a façade design to improve the performance of the base-case scenario. The ribbed stem is translated into a morphology regulating heat by expanding and contracting triggered by temperature difference. As the form of a stem is a sphere but through giving it dimension by the ribs, it becomes geometrically heterogeneous and hosts another function of shading. This achieves cooling between the ribbed surfaces instead of reaching extreme temperatures otherwise without ribs. The self-shading areoles and spines texture is translated into an opacity-changing glazing (photochromic) regulating light and solar gains triggered by solar radiation. The photochromic glazing chemically changes its properties various solar heat gain coefficient and visible light transmittance values to different levels of solar irradiance [113]. This is similar to having an additional function through heterogeneous surface properties. The heterogeneous morphology and the hierarchical shading material together achieve multifunctionality. The stomata are translated into openings regulating heat and air triggered by heat for ventilation. This presents hosting another function by hierarchy and combine with the other two mechanisms interdependently, as it is linked to the ribbed morphology. Therefore, the design hosts two functions at its hierarchical and heterogeneous structure (Figure 14).

The Bio-ABS design is a folding module with an expanding and contracting mechanism activated by temperature difference through the use of thermally restrictive smart material of shape memory alloys (SMAs). SMAs change their length when exposed to differences in solar radiation levels [114,115]. Through this morphology, the design forms a ribbed structure while creating openings for ventilation. The opening's size is controlled by the actuator's displacement, as a percentage of contraction in length. The component is formed by isosceles triangle shaped creases connected by mountain folds and divided into two identical creases by valley folds. The design is a symmetric double-line vertex of degree 6-case rigid origami with a hexagonal base, as hexagon offers improved mechanical properties. The double-line technique allows the creases to have a gap for material thickness. Folds allow the component to change its shape while keeping the triangular creases rigid. A selected material placed in the central point can trigger the system with by a pull and push force into a pattern similar to the biomechanics of the rib structure of Echinocactus grusonii. The second function is achieved by color 
changing smart materials called chromogenics that present an example for functional surface material properties. A study on visualizing the façade on the base-case reference building through replacing its windows with 188 modules is presented in Figure 15.
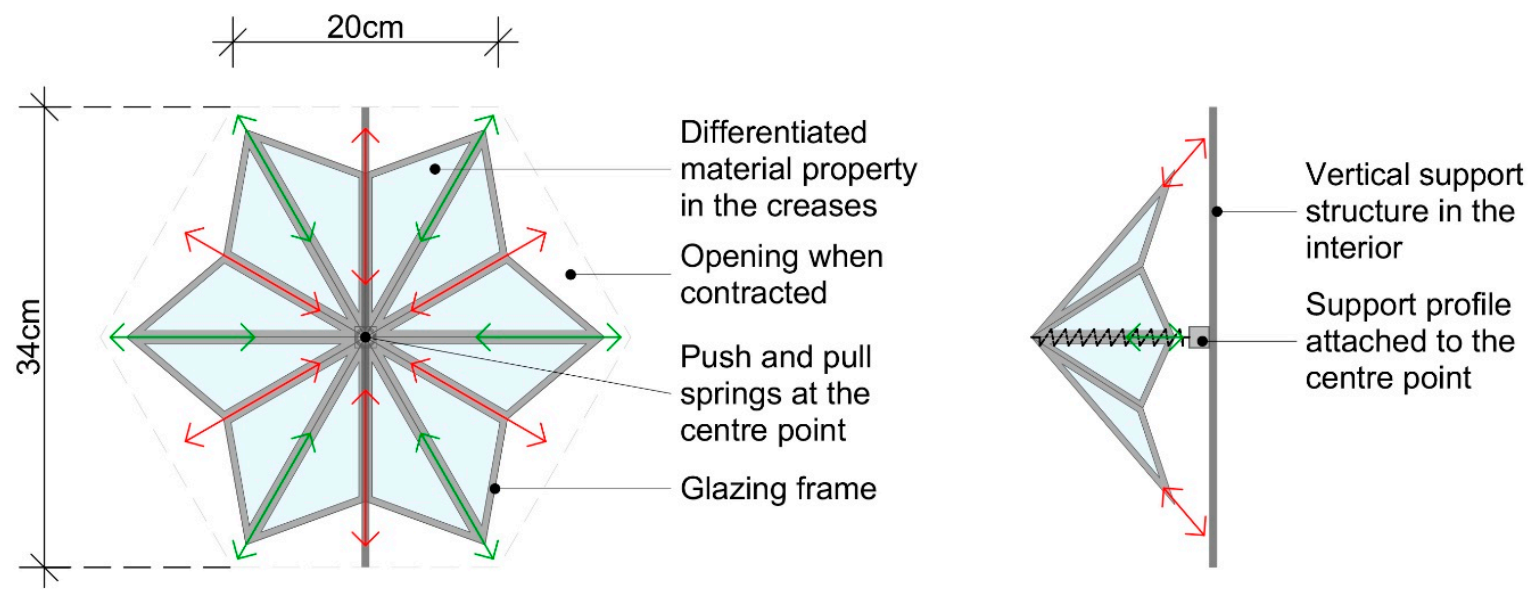

Figure 14. Movement and dimensions of the façade module in elevation and section, where red arrows represent the displacement of valley folds and green arrows represent the displacement of mountain folds.

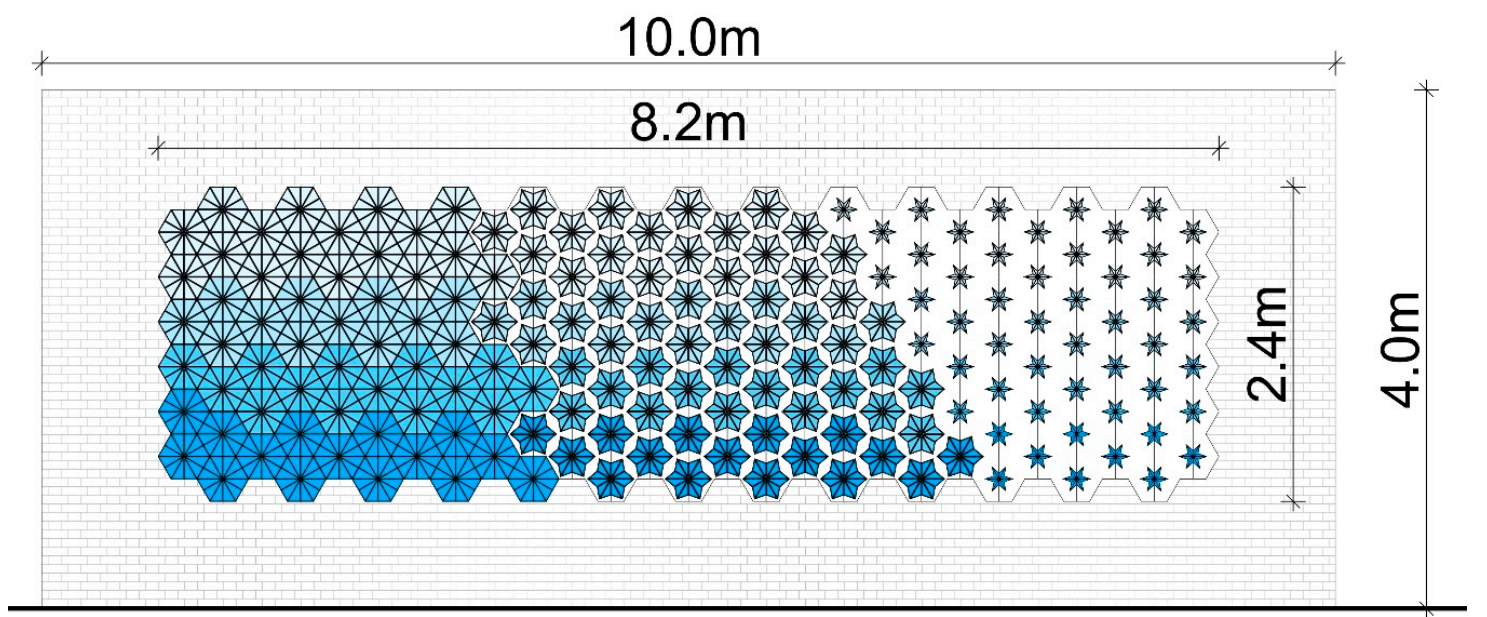

Figure 15. The pattern the Bio-ABS module, with various changing configurations, when implemented on the reference building's windows consisting of 188 modules; from left to right opening ratio increases and from bottom to top glazing opacity decreases.

The aesthetics of this system exist in the built and designed realm, for instance, the dynamic shading façade on the Al Bahar Tower in Abu Dhabi [116]. However, the operation and performance of this design differ significantly, in that they manage multiple parameters (ventilation and shade). As another difference, this design integrates the smart materials of shape memory alloys and photochromic cells within its mechanisms and therefore having a passive operation of the system. As such, Al Bahar Towers are automated through building management system (BMS) that uses electricity [116]. Therefore, most designs in the area with similar constructions are active, meaning they are operated by electricity $[116,117]$. Those designs are mostly programmed to operate at certain situations and therefore they are not considered as fully climate adaptable. The morphological movement of the origami folds is known, while the parameters that control the movement are unique, including the thermally activated pull and push through the central point. Another difference is the integration of hierarchical scales and heterogeneous material properties into this design. Most existing similar designs 
perform a single function and do not consider the integration of multi-scale and multi-dimension transferred from the natural design principles of hierarchy and heterogeneity, respectively.

\subsection{Comparative Analysis of Environmental Performance Evaluation}

To quantify the performance improvement Bio-ABS offer, a comparative analysis with the base-case building is done through building performance simulation. Only one thermal zone, a classroom is modeled to simplify the process (Figure 16). The ventilation type is switched to natural ventilation from mechanical ventilation to determine thermal comfort through the Adaptive Model. Glazing type and its thermal properties, aperture ratio, and ventilation rate are compliant with National Construction Code (NCC) of Australian Building Codes Board (Table 6) [118,119].
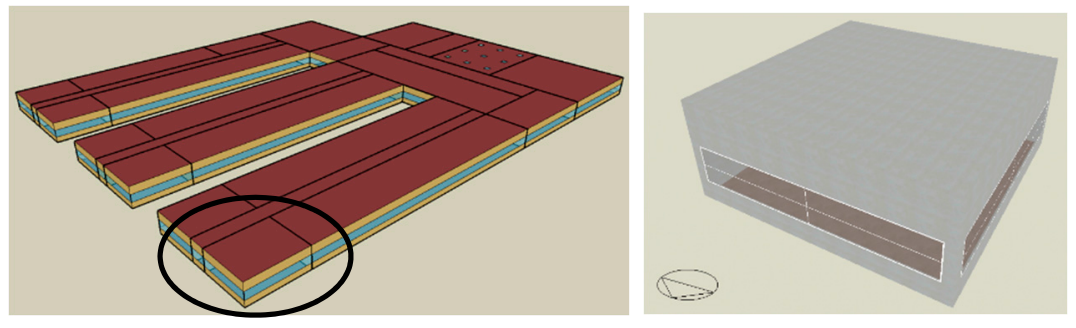

Figure 16. Base-case building.

Table 6. Performance descriptors of the base-case building.

\begin{tabular}{ccc}
\hline Performance Descriptor & Value & Reference \\
\hline Lighting load & $8 \mathrm{~W} / \mathrm{m}$ & \\
Equipment load & $5 \mathrm{~W} / \mathrm{m}$ & \\
Occupants density & 0.4 people $/ \mathrm{m}$ & \\
Ventilation operation schedule & Temperature & {$[118,119]$} \\
Window-to-wall ratio & $40 \%$ & \\
Glazing opening ratio & $25 \%$ & \\
Glazing thermal transmittance & $1.786 \mathrm{~W} / \mathrm{m}^{2} \mathrm{~K}$ & \\
\hline Glazing solar heat gain coefficient & 0.39 & \\
Floor area & $97 \mathrm{~m}$ & \\
Zone volume & $388 \mathrm{~m}$ & \\
Floor-to-ceiling height & $4 \mathrm{~m}$ & \\
External walls thermal resistance & $1.469 \mathrm{~W} / \mathrm{mK}$ & \\
\hline Air change rate & $7.5 \mathrm{ac} / \mathrm{h}$ & \\
\hline
\end{tabular}

Building performance simulation is performed to determine thermal comfort analysis of the base-case building using EnergyPlus. The climate file used is available at EnergyPlus Weather for Sydney IWEC (International Weather for Energy Calculations) station number 947,670. Thermal comfort is calculated through the adaptive model and found that according to $90 \%$ Acceptability Limits (A.L.), $74.03 \%$ of the time occupied does not fall in the comfort zone with $1588 \mathrm{~h}$ of discomfort and according to $80 \%$ A.L., it is $38.14 \%$ with $818.25 \mathrm{~h}$ of discomfort (The calculation follows the presence of occupants on a daily basis in weekdays from $08: 00 \mathrm{am}$ to $16: 00 \mathrm{pm}$ by a fraction of 0.75 and from $16: 00 \mathrm{pm}$ to $21: 00 \mathrm{pm}$ by a fraction of 0.15 ) (Table 7).

Table 7. Comfort analysis of the base-case building.

\begin{tabular}{cccc}
\hline Analysis Type & Acceptability Limits & Discomfort Hours & Discomfort Ratio \\
\hline Adaptive thermal & $90 \%$ & $1588 \mathrm{~h}$ & $74.03 \%$ \\
comfort & $80 \%$ & $818.25 \mathrm{~h}$ & $38.14 \%$ \\
\hline
\end{tabular}


The simulation results are analyzed to understand the causes for increased discomfort ratio. The results show that maximum values for indoor temperatures are calculated as $37^{\circ} \mathrm{C}$ for mean radiant and $38^{\circ} \mathrm{C}$ for operative and air temperatures. This suggests that the maximum temperatures are above the limits for temperature, that is, $33-33.5^{\circ} \mathrm{C}$. Moreover, the windows and infiltration are identified as the causes for heat loss with values of $18 \mathrm{kWh} / \mathrm{m}^{2}$ and $41 \mathrm{kWh} / \mathrm{m}^{2}$, respectively. The evaluation shows that the base-case building suffers high temperatures and excessive heat gains. This suggests that solar gains negatively impact comfort in the building and the regulation of heat and light must be addressed to improve the performance (Figure 17).

The windows of the base-case building are replaced with the Bio-ABS design and the performance is analyzed through simulation. The multifunctional Bio-ABS is modeled in EnergyPlus using its feature EMS, that integrates customizable input-output objects and allows using if statements. The photochromic (PC) glazing is modeled with its four states changing the solar heat gain coefficient (SHGC $=0.508,0.396,0.325,0.238)$ and visible light transmittance $(\mathrm{VLT}=0.595,0.446,0.341,0.238)$ with a fixed thermal transmittance $\left(\mathrm{U}\right.$-value $\left.=1.786 \mathrm{~W} / \mathrm{m}^{2} \mathrm{~K}\right)$. The $\mathrm{U}$-value of the base-case building and the case study are the same. The SHGC and VLT of the base-case building are calculated as the average values of the four states of the case study. The properties of the PC glazing are taken from a previous study outlining the performance improving PC glazing systems for the chosen climatic context [82]. The properties of the morphology triggering Shape Memory Alloys (SMAs) are set to demonstrate a comparable case against the base-case, which provides the same window opening ratio $(25 \%)$ with a corresponding SMA displacement ratio. Other properties of the SMA including the actuation $\left(18^{\circ} \mathrm{C}\right)$ and de-actuation temperatures $\left(60^{\circ} \mathrm{C}\right)$ are determined to provide an adaptable system operated by changes in temperature. The simulation results after replacing the base-case building's windows with the Bio-ABS show a decrease in discomfort hours by $23.18 \%$ for $90 \%$ A.L. and $5.09 \%$ for $80 \%$ A.L. (Figure 18).

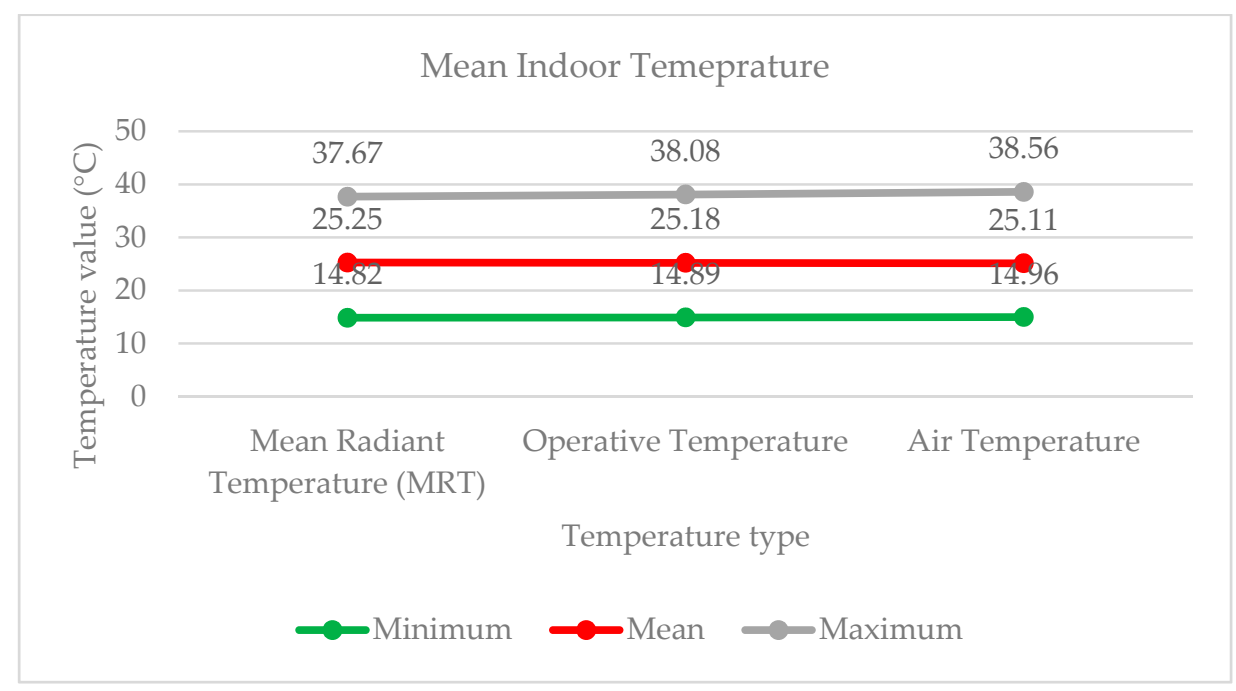

Figure 17. Indoor temperature analysis of the base-case building, where the gray line presents the maximum, red line presents the mean and the green line presents the minimum values.

The mean values for the indoor temperatures of mean radiant, mean operative, and mean air temperatures are decreased (Figure 19). The mean value for MRT is decreased by $2.23^{\circ} \mathrm{C}$, the mean value for operative temperature is decreased by $2.76^{\circ} \mathrm{C}$, and the mean value for air temperature is decreased by $3.28^{\circ} \mathrm{C}$. Overall, the implementation of this multifunctional Bio-ABS improves the thermal comfort in an educational building in Sydney. This study has focused on the integration of a PC glazing and SMA activated ventilation with set values for its performance descriptors (i.e., actuation temperature, SHGC, VLT). Further work could investigate different living systems, their functional 
transfer into multifunctional engineered designs, consider different performance descriptors of Bio-ABS, and simulate their environmental performance.

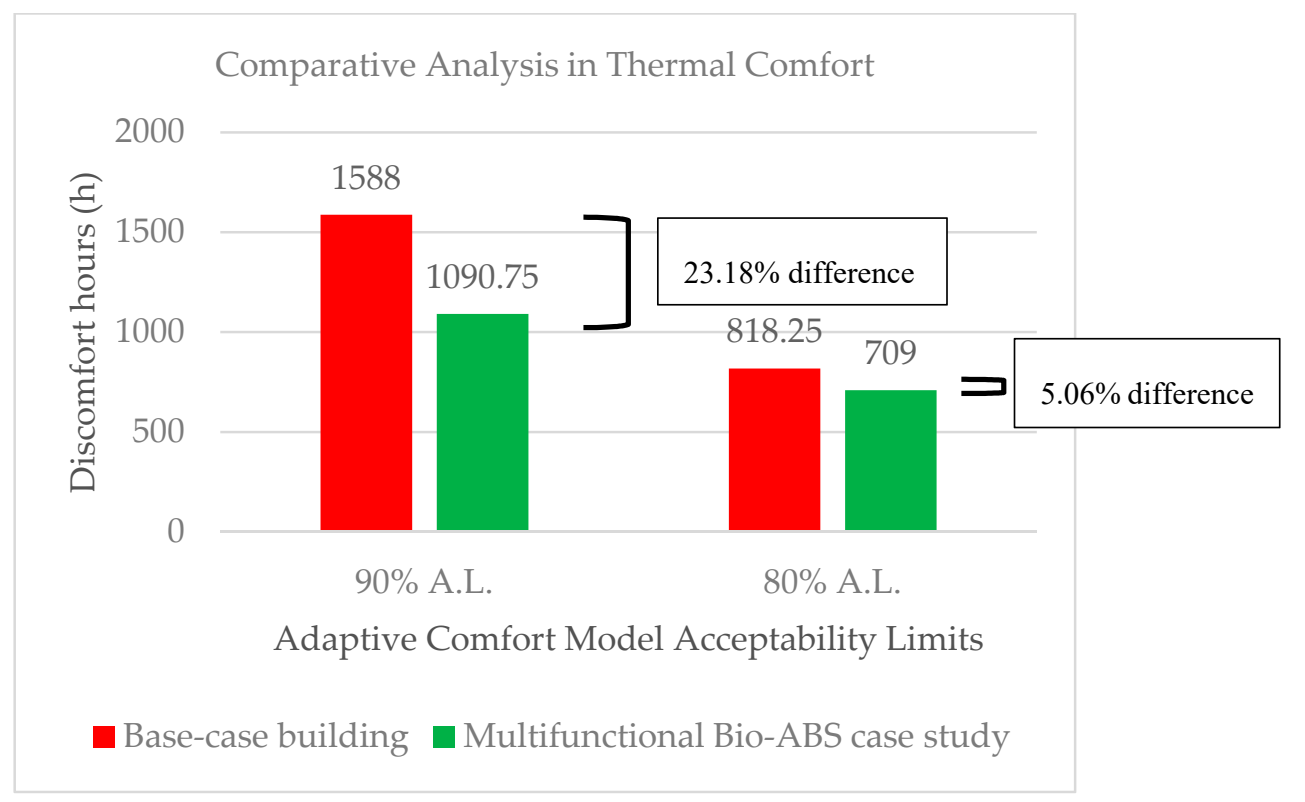

Figure 18. Comparative analysis in thermal comfort between the base-case building and the multifunctional Bio-ABS case study.

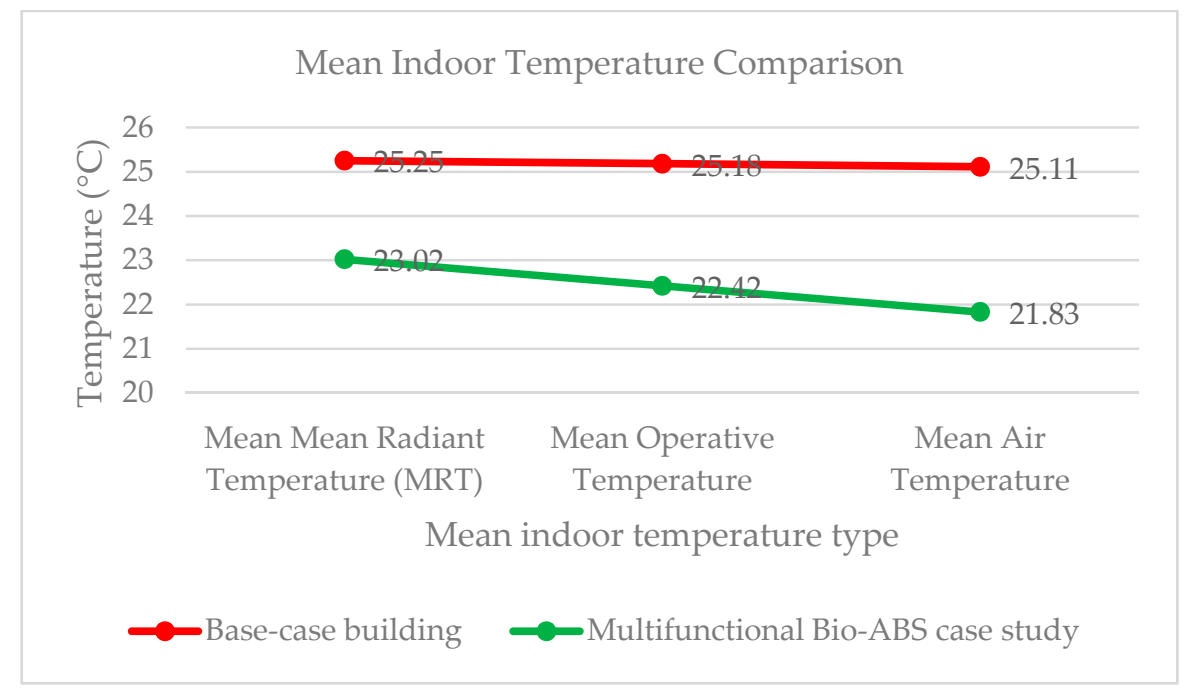

Figure 19. Mean indoor temperature comparison between the base-case building, and the case study.

\section{Conclusions}

This paper presents a framework for achieving multifunctionality in Bio-ABS. It does so by translating hierarchy and heterogeneity from nature into architecture. A systematic classification to map biological systems from the perspective of how they host multiple functions in their heterogeneous multi-level structures is presented. Several biological systems are mapped using the classification to define a "preliminary database" to categorize biological data. This database could be expanded over time to create a systemic collection of biological information as a resource for biomimetic design.

Hierarchy and heterogeneity in nature are described and their transfer into designs can achieve multifunctionality. Hierarchy is described as having multiple scales and heterogeneity as multiple geometric differentiations. Their transfer into Bio-ABS is proposed through a framework named the "Multi-Biomechanism Approach", that uses the systematic classification. The framework is 
demonstrated through the case study of translating Echinocactus grusosnii and three of its many biological adaptations: rib structured cortex, self-shading areoles and spines, and microscopic stomatal openings. A Bio-ABS design is presented showing how the hierarchical features of the areoles, spines, and stomatal openings, as well as the heterogeneous form of the ribs structure can be translated into a biomimetic strategy integrated in a building skin.

The base-case building and the case study of the multifunctional Bio-ABS replacing the windows of the base-case building are simulated to calculate their performance. The comparative analysis of the results show that Bio-ABS offer improved comfort both for $80 \%$ and $90 \%$ Acceptability Limits according to Adaptive Comfort Model. The mean value for MRT is decreased by $2.23^{\circ} \mathrm{C}$, the mean value for operative temperature is decreased by $2.76{ }^{\circ} \mathrm{C}$, and the mean value for air temperature is decreased by $3.28{ }^{\circ} \mathrm{C}$. Overall, the results after replacing the base-case building's windows with the Bio-ABS show a decrease in discomfort hours by $23.18 \%$ for $90 \%$ Acceptability Limits and $5.09 \%$ for $80 \%$ A.L. for adaptive thermal comfort.

As results of the work carried out and the findings, this research draws attention to multifunctionality in nature and in engineered designs, particularly of Bio-ABS, and promotes biomimetic design as a promising approach to be taken to develop environmentally sustainable building systems. This study attempts to point out the significance of the "natural design principles" and their limited application in architecture. However, it is limited to the translation of hierarchy and heterogeneity, excluding others that may help achieving multifunctionality, which further work can focus.

Author Contributions: A.K.: Conceptualization, methodology, software, formal analysis, investigation, resources, data curation, writing — original draft, writing—review \& editing, visualization, funding acquisition. P.O.: Conceptualization, methodology, formal analysis, investigation, resources, data curation, writing-original draft, writing-review \& editing, visualization, funding acquisition, supervision. S.B.: Conceptualization, methodology, formal analysis, investigation, resources, data curation, writing - review \& editing, funding acquisition, supervision. F.F.: Conceptualization, methodology, software, formal analysis, investigation, resources, data curation, writing-review \& editing, funding acquisition, supervision. All authors have read and agreed to the published version of the manuscript.

Funding: This work was supported by the Faculty of Built Environment at UNSW Sydney under Grant Wightman PG School Architecture (PGA1005).

Acknowledgments: The authors acknowledge the support provided by UNSW Sydney.

Conflicts of Interest: The authors declare no conflict of interest.

\section{References}

1. Hasselaar, B.L. Climate adaptive skins: Towards the new energy-efficient façade. In Proceedings of the 1st International Conference on the Management of Natural Resources, Sustainable Development and Ecological Hazards; 2006; pp. 351-360. Available online: https://www.scribd.com/document/458674117/ WIT-transactions-on-ecology-and-the-environment-volume-99-C-A-Brebbia-Management-of-NaturalResources-Sustainable-Development-And-Ecological-Ha (accessed on 1 June 2020).

2. Del Grosso, A.E.; Basso, P. Adaptive building skin structures. Smart Mater. Struct. 2010, 19, 124011. [CrossRef]

3. Loonen, R.C.; Trcka, M.; Costola, D.; Hensen, J.L. Climate adaptive building shells: State-of-the-art and future challenges. Renew. Sustain. Energy Rev. 2013, 25, 483-493. [CrossRef]

4. Aelenei, D. Adaptive Façade: Concept, Applications, Research Questions. Energy Procedia 2016, 91, $269-275$. [CrossRef]

5. Kuru, A.; Oldfield, P.; Bonser, S.; Fiorito, F. Biomimetic adaptive building skins: Energy and environmental regulation in buildings. Energy Build. 2019, 205, 109544. [CrossRef]

6. Gruber, P. Biomimetics in Architecture; Springer Verlag Wien: Wien, Austria, 2011.

7. Vincent, J.F.; Bogatyreva, O.A.; Bogatyrev, N.R.; Bowyer, A.; Pahl, A.K. Biomimetics: Its practice and theory. J. R. Soc. Interface 2006, 3, 471-482. [CrossRef] [PubMed]

8. Bar-Cohen, Y. (Ed.) Biomimetics: Nature-Based Innovation; CRC Press, Taylor and Francis Group Publishing: Boca Raton, FL, USA, 2012. 
9. López, M.; Rubio, R.; Martín, S.; Croxford, B.; Jackson, R. Active materials for adaptive architectural envelopes based on plant adaptation principles. J. Facade Des. Eng. 2015, 3, 27-38. [CrossRef]

10. Badarnah Kadri, L. Towards the LIVING Envelope: Biomimetics for Building Envelope Adaptation. Ph.D. Thesis, Technical University Delft, Delft, The Netherlands, 2015.

11. Kuru, A.; Fiorito, F.; Oldfield, P.; Bonser, S.P. Multi-functional biomimetic adaptive façades: A case study. In Proceedings of the FACADE 2018 Final Conference of COST TU1403 Adaptive Facades Network, Lucerne, Switzerland, 26-27 November 2018; pp. 241-250.

12. Badarnah, L. Form follows environment: Biomimetic approaches to building envelope design. Buildings 2017, 7, 40. [CrossRef]

13. López, M.; Rubio, R.; Martín, S.; Croxford, B. How plants inspire façades. From plants to architecture: Biomimetic principles for the development of adaptive architectural envelopes. Renew. Sustain. Energy Rev. 2017, 67, 692-703. [CrossRef]

14. Vincent, J.F.V.; Mann, D.L. Systematic technology transfer from biology to engineering. Philos. Trans. Math. Phys. Eng. Sci. 2002, 15, 159-173. [CrossRef] [PubMed]

15. Shu, L.H. A natural-language approach to biomimetic design. Artif. Intell. Eng. Des. Anal. Manuf. 2010, 24, 507-519. [CrossRef]

16. Helms, M.; Vattam, S.S.; Goel, A.K. Biologically inspired design: Process and products. Des. Stud. 2009, 30, 606-622. [CrossRef]

17. Biomimicry Institute. Biomimicry.net: Biomimicry 3.8. Available online: http://biomimicry.net/ (accessed on 25 June 2020).

18. Hirtz, J.; Stone, R.B.; McAdams, D.A.; Szykman, S.; Wood, K.L. A functional basis for engineering design: Reconciling and evolving previous efforts. Res. Eng. Des. Theory Appl. Concurr. Eng. 2002, 13, 65-82. [CrossRef]

19. Biomimicry Institute. AskNature: A Project of Biomimicry 3.8. Available online: www.asknature.org (accessed on 24 June 2020).

20. Vincent, J.F.V. Research and Practice on the Theory of Inventive Problem Solving (TRIZ); Springer: Berlin, Germany, 2016.

21. Bogatyrev, N.; Bogatyreva, O. TRIZ evolutionary trends in biology and technology: Two opposites. In Proceedings of the CIRP Design Conference, Cranfield, UK, 30-31 March 2009; p. 293.

22. Wilson, J.O. A Systematic Appraoch to Bio-Inspired Conceptual Design. Ph.D. Thesis, Georgia Institute of Technology, Atlanta, GA, USA, 2008.

23. Gamage, R.S.D.; Wickramanayake, A.U. Parallels between nature and design teaching through nature studies. Built Environ. Sri Lanka 2005, 5, 1-12.

24. Svendsen, N.; Torben, L.A. How does biologically inspired design cope with multi-functionality? In Proceedings of the International Conference on Engineering Design ICED19, Delft, The Netherlands, 5-8 August 2019; pp. 349-358.

25. Cruz, E.; Raskin, K.; Aujard, F. Biological strategies for adpative building envelopes. In Proceedings of the FACADE 2018 Final Conference of COST TU1403 Adaptive Facades Network, Lucerne, Switzerland, 26-27 November 2018; pp. 223-229.

26. Kuru, A.; Fiorito, F.; Oldfield, P.; Bonser, S.P. Multi-functional biomimetic adaptive façades: Developing a framework. In Proceedings of the FACADE 2018 Final Conference of COST TU1403 Adaptive Facades Network, Lucerne, Switzerland, 26-27 November 2018; pp. 231-240.

27. Fratzl, P.; Dunlop, J.; Weinkamer, R. Materials Design Inspired by Nature: Function through Inner Architecture; RSC Publishing-Royal Society of Chemisstry: Cambridge, UK, 2013.

28. Fratzl, P.; Weinkamer, R. Nature's hierarchical materials. Prog. Mater. Sci. 2007, 52, 1263-1334. [CrossRef]

29. Dunlop, J.W.C.; Fratzl, P. Biological composites. Ann. Rev. Mater. Res. 2010, 40, 1-24. [CrossRef]

30. Knippers, J.; Speck, T. Design and construction principles in nature and architecture. Bioinspir. Biomim. 2012, 7, 15002. [CrossRef] [PubMed]

31. Jeronimidis, G.; Atkins, A.G. Mechanics of biological materials and structures: Nature's lessons for the engineer. Proc. Inst. Mech. Eng. 1995, 209, 221-235. [CrossRef]

32. Burgert, I.; Fratzl, P. Actuation systems in plants as prototypes for bioinspired devices. Philos. Trans. R. Soc. A Math. Phys. Eng. Sci. 2009, 367, 1541-1557. [CrossRef] 
33. Pedersen Zari, M. Ecosystem processes for biomimetic architectural and urban design. Archit. Sci. Rev. 2014, 58, 106-119. [CrossRef]

34. John, G.; Clements-Croome, D.; Jeronimidis, G. Sustainable building solutions: A review of lessons from the natural world. Build. Environ. 2005, 40,319-328. [CrossRef]

35. Garcia-Holguera, M.; Clark, O.G.; Sprecher, A.; Gaskin, S. Ecosystem biomimetics for resource use optimization in buildings. Build. Res. Inf. 2016, 44, 263-278. [CrossRef]

36. Appio, F.P.; Achiche, S.; Martini, A. On designers' use of biomimicry tools during the new product development process: An empirical investigation. Technol. Anal. Strateg. Manag. 2017, 29, 775-789. [CrossRef]

37. Pedersen Zari, M. Biomimetic Approaches To Architectural Design for Increased Sustainability. In Proceedings of the SB07 NZ Sustainable Building Conference, Auckland, New Zealand, 14-16 November 2017.

38. Hastrich, C. The biomimicry design spiral. Biomimicry Newsl. 2006, 4, 5-6.

39. Ahmar, S.E.; Fioravanti, A.; Hanafi, M. A Methodology for Computational Architectural Design Based on Biological Principles. In Proceedings of the 31st eCAADe Conference, Delft, The Netherlands, 18-20 September 2013.

40. Sheta, A.A.A.A. Biomimicry in Environmental Architecture: Exploring the Concept and Methods of the Bio-Inspired Environmental Architecrural Design. 2010. Available online: http://www.cpas-egypt.com/pdf/ Ayat_El-Jawhary/MS.c/MS.c.pdf (accessed on 25 June 2020).

41. Badarnah, L.; Kadri, U. A methodology for the generation of biomimetic design concepts. Archit. Sci. Rev. 2014, 8628, 1-14. [CrossRef]

42. Cohen, Y.H.; Reich, Y.; Greenberg, S. What can we learn from biological systems when applying the law of system completeness? Procedia Eng. 2015, 131, 104-114. [CrossRef]

43. Chakrabarti, A.; Siddharth, L.; Dinakar, M. Idea Inspire 3.0-A tool for analogical design. In Research into Design for Communities; Smart Innovation, Systems and Technologies; 2017; Volume 2, pp. 475-485. Available online: https://link.springer.com/chapter/10.1007\%2F978-981-10-3521-0_41 (accessed on 25 June 2020).

44. Goel, A.; Rugaber, S.; Vattam, S. Structure, Behavior and Function of complex systems: The SBF Modeling Language. Artif. Intell. Eng. Des. Anal. Manuf. 2009, 23, 23-25. [CrossRef]

45. Gamage, A.; Hyde, R. A model based on biomimicry to enhance ecologically sustainable design. Archit. Sci. Rev. 2012, 55, 224-235. [CrossRef]

46. Schleicher, S.; Lienhard, J.; Poppinga, S.; Speck, T.; Knippers, J. A methodology for transferring principles of plant movements to elastic systems in architecture. Comput. Des. 2015, 60, 105-117. [CrossRef]

47. Pedersen Zari, M. Ecosystem services analysis for the design of regenerative built environments. Build. Res. Inf. 2012, 40, 54-64. [CrossRef]

48. Lienhard, J.; Schleicher, S.; Poppinga, S.; Masselter, T.; Milwich, M.; Speck, T.; Knippers, J. Flectofin: A hingeless flapping mechanism inspired by nature. Bioinspir. Biomim. 2011, 6, 045001. [CrossRef]

49. Badarnah, L.; Knaack, U. Shading/Energy generating skin inspired from natural systems. In Proceedings of the 2008 World Sustainable Building Conference: SB08, Melbourne, Australia, 21-15 September 2008; pp. 305-312.

50. Goel, A.G.; Mcadams, D.A.; Stone, R.B. (Eds.) Biologically Inspired Design: Computational Methods and Tools; Springer: London, UK, 2014.

51. Martone, P.T.; Boller, M.; Burgert, I.; Dumais, J.; Edwards, J.; Mach, K.; Rowe, N.; Rueggeberg, M.; Seidel, R.; Speck, T. Mechanics without muscle: Biomechanical inspiration from the plant Wworld. Integr. Comp. Biol. 2010, 50, 888-907. [CrossRef] [PubMed]

52. Rowe, N.P.; Speck, T. Hydraulics and mechanics of plants: Novelty, innovation and evolution. In The Evolution of Plant Physiology; Academic, A.R., Poole, I., Eds.; Elsevier: London, UK, 2004; pp. 301-329.

53. Garland, T. Quick guide: Tradeoffs. Curr. Biol. 2014, 24, 60-61. [CrossRef] [PubMed]

54. Knaack, U.; Klein, T.; Bilow, M.; Auer, T. Facades: Principles of Construction, 2nd ed.; BIRKHAUSER: Berlin, Germany, 2014.

55. Prieto, A.; Knaack, U.; Auer, T.; Klein, T. Passive cooling \& climate responsive façade design: Exploring the limits of passive cooling strategies to improve the performance of commercial buildings in warm climates Energy \& Buildings Passive cooling \& climate responsive façade design exploring the. Energy Build. 2018, $175,30-47$.

56. Gruber, P. Has biomimetics arrived in architecture? Bioinspir. Biomim. 2012, 7, 010201. [CrossRef] 
57. Fiorito, F.; Sauchelli, M.; Arroyo, D.; Pesenti, M.; Imperadori, M.; Masera, G.; Ranzi, G. Shape morphing solar shadings: A review. Renew. Sustain. Energy Rev. 2016, 55, 863-884. [CrossRef]

58. Palomo, I.; Dujardin, Y.; Midler, E.; Robin, M.; Sanz, M.; Pascual, U. Modeling trade-offs across carbon sequestration, biodiversity conservation, and equity in the distribution of global REDD+ funds. In Proceedings of the National Academy of Sciences, 21 October 2019; Volume 116, pp. 22645-22650. [CrossRef]

59. Speck, T.; Rowe, N. How to become a successful climber-mechanical, anatomical, ultra-structrural and biochemical variations during ontogeny in plants with different climbing strategies. In Proceedings of the 5th International PLant Biomechanics Conference, Lausanne, Switzerland, 21-23 May 2007; Volume 1, pp. 103-108.

60. Al-Obaidi, K.M.; Ismail, M.A.; Hussein, H.; Abdul, A.M. Biomimetic building skins: An adaptive approach. Renew. Sustain. Energy Rev. 2017, 79, 1472-1491. [CrossRef]

61. Levitt, J. Physiological basis of stomatal response. In Water and Plant Life; Springer: Berlin/Heidelberg, Germany, 1976; Volume 19.

62. Bertolino, L.T.; Caine, R.S.; Gray, J.E. Impact of stomatal density and morphology on Water-Use efficiency in a changing world. Front. Plant Sci. 2019, 10,1-11. [CrossRef]

63. Ye, H.; Yuan, Z.; Zhang, S. The heat and mass transfer analysis of a leaf. J. Bionic Eng. 2013, 10, $170-176$. [CrossRef]

64. Nobel, P.S. Water relations and photosynthesis of a barrel cactus, Ferocactus acanthodes, in the Colorado desert. Oecologia 1977, 27, 117-133. Available online: https://link.springer.com/article/10.1007/BF00345817 (accessed on 25 June 2020). [CrossRef]

65. Decker, M. Emergent Futures: Nanotechnology and emergenct materials in architecture. In Proceedings of the BTES Conference 2013-Tectonics of Teaching Roger Williams University, New Jersey Institite of Technology, Bristol, RI, USA, 11-13 July 2013.

66. Schinegger, K.; Rutzinger, S.; Oberascher, M.; Weber, G. One Ocean: Theme Pavilion EXPO 2012 Yeosu, Residenz Verlag. Available online: http://www.soma-architecture.com/index.php?page=theme_pavilion\& parent $=2$ (accessed on 25 June 2020).

67. Reichert, S.; Menges, A.; Correa, D. Meteorosensitive architecture: Biomimetic building skins based on materially embedded and hygroscopically enabled responsiveness. Comput. Des. 2015, 60, 50-69. [CrossRef]

68. Menges, A. HygroScope: Meteorosensitive morphology. In Proceedings of the Project Catalogue of the 32nd Annual Conference of the Association for Computer-Aided Design in Architecture ACADIA, San Francisco, CA, USA, 18-21 October 2012.

69. Henrion, W.; Tributsch, H. Optical solar energy adaptations and radiative temperature control of green leaves and tree barks. Sol. Energy Mater. Sol. Cells 2009, 93, 98-107. [CrossRef]

70. Jeronimidis, G. Design and function of structural biological materials. Pergamon Mater. Ser. 2000, 4, 19-29.

71. Schleicher, S. Bio-Inspired Compliant Mechanisms for Architectural Design: Transferring Bending and Folding Principles of Plant Leaves to Flexible Kinetic Structures; University of Stuttgart: Stuttgart, Germany, 2016.

72. Speck, T.; Knippers, J.; Speck, O. Self- $X$ materials and structures in nature and technology: Bio-inspiration as a driving force for technical innovation. Archit. Des. 2015, 85, 34-39. [CrossRef]

73. Vukusic, P.; Sambles, J.R.; Lawrence, C.R.; Wootton, R.J. Quantified interference and diffraction in single Morpho butterfly scales. Proc. R. Soc. B Biol. Sci. 1999, 266, 1403-1411. [CrossRef]

74. Yoshioka, S.; Kinoshita, S. Wavelength-selective and anisotropic light-diffusing scale on the wing of the Morpho butterfly. Proc. R. Soc. Publ. Biol. Sci. 2004, 271, 581-587. [CrossRef] [PubMed]

75. Prum, R.O. Anatomically diverse butterfly scales all produce structural colours by coherent scattering. J. Exp. Biol. 2006, 209, 748-765. [CrossRef] [PubMed]

76. Bui, D.K.; Nguyen, T.N.; Ghazlan, A.; Ngo, N.T. Enhancing building energy efficiency by adaptive façade: A computational optimization approach. Appl. Energy 2020, 265, 114797. [CrossRef]

77. Sheikh, W.T.; Asghar, Q. Adaptive biomimetic facades: Enhancing energy efficiency of highly glazed buildings. Front. Archit. Res. 2019, 8, 319-331. [CrossRef]

78. Park, B.R.; Hong, J.; Choi, E.J.; Choi, Y.J.; Lee, C. Improvement in energy performance of building envelope incorporating electrochromic windows (ECWs). Energies 2019, 12, 1181. [CrossRef] 
79. Giovannini, L.; Favoino, F.; Pellegrino, A.; Lo Verso, V.R.M.; Serra, V.; Zinzi, M. Thermochromic glazing performance: From component experimental characterisation to whole building performance evaluation. Appl. Energy 2019, 251, 113335. [CrossRef]

80. Svetozarevic, B.; Begle, M.; Jayathissa, P.; Caranovic, S.; Shephard, R.F.; Nagy, Z.; Hischier, I.; Hofer, J.; Schluter, A. Dynamic photovoltaic building envelopes for adaptive energy and comfort management. Nat. Energy 2019, 4, 671-682. [CrossRef]

81. Gao, Y.; Dong, J.; Isabella, O.; Santbergen, R.; Tan, H.; Zeman, M.; Zhang, G. A photovoltaic window with sun-tracking shading elements towards maximum power generation and non-glare daylighting. Appl. Energy 2018, 228, 1454-1472. [CrossRef]

82. Fiorito, F.; Cannavale, A.; Santamouris, M. Development, testing and evaluation savings potentials of photovoltachromic windows in office buildings. A perspective study for Australian climates. Sol. Energy 2020, 205, 358-371. [CrossRef]

83. Loonen, R.C.G.M.; Favoino, F.; Hensen, J.L.M.; Overend, M. Review of current status, requirements and opportunities for building performance simulation of adaptive facades. J. Build. Perform. Simul. 2016, 1493, 1-19. [CrossRef]

84. Loonen, R. Approaches for Computational Performance Optimization of Innovative Adaptive Façade Concepts; Issue 153 Bouwstenen series of the Department of the Built Environment; Eindhoven University of Technology: Eindhoven, The Netherlands, 2018.

85. Bhushan, B.; Jung, Y.C. Natural and biomimetic artificial surfaces for superhydrophobicity, self-cleaning, low adhesion, and drag reduction. Prog. Mater. Sci. 2011, 56, 1-108. [CrossRef]

86. Gorb, S.; Speck, T. Biological and biomimetic materials and surfaces. Beilstein J. Nanotechnol. 2017, 8, $403-407$. [CrossRef]

87. Garrett, T.Y.; Huynh, C.; North, G.B. Root contraction helps protect the "Living rock" cactus Ariocarpus fissuratus from lethal high temperatures when growing in rocky soil temperatures when growing in rocky soil 1. Am. J. Bot. 2010, 97, 1951-1960. [CrossRef]

88. Worall, M. Intelligent thermoregulation and homeostasis: Lessons from nature. In Proceedings of the CIB World Congress, Salford, UK, 11-13 May 2010.

89. Badarnah, L. Light Management Lessons from Nature for Building Applications. In Proceedings of the International Conference on Sustainable Design, Engineering and Construction, Tempe, AZ, USA, 18-20 May 2016; Volume 145, pp. 595-602.

90. Helfman, Y.C.; Reich, Y. Biomimetic Design Method for Innovation and Sustainability; Springer: Berlin, Germany, 2016.

91. Gruber, P. Transfer of nature to architecture-Analysis of case studies. In Proceedings of the Biological Approaches for Engineering Conference, University of Southampton, Southampton, UK, 17-19 March 2008.

92. Mazzoleni, I. Architecture Follows Nature; Taylor \& Francis: Oxfordshire, UK, 2013.

93. Pawlyn, M. Biomimicry in Architecture; RIBA Publishing: London, UK, 2011.

94. Harman, J. The Shark's Paintbrush: Biomimicry and How Nature Is Inspiring Innovation; Knopf Doubleday Publishing Group: New York, NY, USA, 2013.

95. Kapsali, V. Biomimetics for Designers; Thames and Hudson: London, UK, 2016.

96. Knippers, J.; Nickel, K.G. (Eds.) Biomimetic Research for Architecture and Building Construction: Biological Design and Integrative Structures; Springer International Publishing: Cham, Switzerland, 2016.

97. Pacheco, F.-T.; Labrincha, J.A.; Diamanti, M.V.; Yu, C.P.; Lee, H.K. (Eds.) Biotechnologies and Biomimetics for Civil Engineering; Springer International Publishing: Cham, Switzerland, 2015.

98. Pohl, G.; Nachtigall, W. Biomimetics for Architecture and Design: Nature-Analogies-Technology; Springer: Cham, Switzerland, 2015. [CrossRef]

99. Shi, N.N.; Tsai, C.C.; Camino, F.; Bernard, G.D.; Yu, N.; Wehner, R. Keeping cool: Enhanced optical reflection and radiative heat dissipation in Saharan silver ants. Science 2015, 349, 298-301. [CrossRef]

100. Bhasin, D.; McAdams, D. The characterization of biological organization, abstraction, and novelty in biomimetic design. Designs 2018, 2, 54. [CrossRef]

101. Field, K.J.; George, R.; Fearn, B.; Quick, W.P.; Davey, M.P. Best of both worlds: Simultaneous high-light and shade-tolerance adaptations within individual leaves of the living stone lithops aucampiae. PLoS ONE 2013, 8, e75671. [CrossRef] 
102. Badarnah, L. Environmental adaptation of buildings through morphological differentiation. In Proceedings of the 15th Conference on Advanced Building Skins, Bern, Switzerland, 1-2 October 2018.

103. Gibson, A.; Nobel, P. The Cactus Primer; Harvard University Press: Cambridge, MA, USA, 1986.

104. Bar-Cohen, Y. Biomimetics-Using nature to inspire human innovation. Bioinspir. Biomim. 2006, 1, 1-12. [CrossRef]

105. Bhushan, B. Biomimetics: Lessons from nature-An overview. Philos. Trans. R. Soc. A Math. Phys. Eng. Sci. 2009, 367, 1445-1486. [CrossRef]

106. Bhushan, B. Biomimetics: Bioinspired Hierarchical-Structured Surfaces for Green Science and Technology; Springer: Berlin/Heidelberg, Germany, 2012.

107. Brownell, B.; Swackhamer, M. Hyper-Natural: Architecture's New Relationship with Nature; Princeton Architectural Press: New York, NY, USA, 2015.

108. Laver, J.; Clifford, D.; Vollen, J. High performance masonry wall systems: Principles derived from natural analogues. WIT Trans. Ecol. Environ. 2008, 114, 243-252.

109. Dawson, C.; Vincent, J.F.V.; Rocca, A.M. How pine cones open. Nature 1997, 39, 668. [CrossRef]

110. Mott, K.A.; Gibson, A.C.; Leary, J.W.O. The adaptive significance of amphistomatic leaves. Plant Cell Environ. 1982, 5, 455-460. [CrossRef]

111. Bureau of Meteorology. Climate Statistics for Australian Locations. 2016. Available online: www.bom.gov.au (accessed on 24 June 2020).

112. U.S.D. of Energy. US DoE Documentation. Available online: https://www.environment.gov.au/energy (accessed on 27 June 2020).

113. Casini, M. Active dynamic windows for buildings: A review. Renew. Energy 2018, 119, 923-934. [CrossRef]

114. Formentini, M.; Lenci, S. An innovative building envelope (kinetic façade) with Shape Memory Alloys used as actuators and sensors. Autom. Constr. 2018, 85, 220-231. [CrossRef]

115. Pesenti, M.; Masera, G.; Fiorito, F. Exploration of Adaptive Origami Shading Concepts through Integrated Dynamic Simulations. J. Archit. Eng. 2018, 24, 4018022. [CrossRef]

116. Attia, S. Evaluation of adaptive facades: The case study of Al Bahr Towers in the UAE. QSci. Connect 2017, 6. [CrossRef]

117. Suralkar, R. Solar responsive kinetic facade shading systems inspired by plant mvoements in nature. In Proceedings of the People and Buildings, the offices of Arup UK, Netowkr for Comfort and Energy Use in Buildings, London, UK, 23 September 2011.

118. ABCB. NCC 2019 BCA Volume 1. 2019. Available online: https://ncc.abcb.gov.au/ncc-online/NCC/2019/NCC2019-Volume-One (accessed on 24 June 2020).

119. ABCB. NCC 2019 BCA Volume 2. 2019. Available online: https://ncc.abcb.gov.au/ncc-online/NCC/2019/NCC2019-Volume-Two (accessed on 24 June 2020).

120. Australian Standards. AS 16682 Supplement 1-2002 the Use of Ventilation and Airconditioning in Buildings-Ventilation Design for Indoor Air Contaminant Control. 2016. Available online: https://www. saiglobal.com/PDFTemp/Previews/OSH/as/as1000/1600/N16682S1.pdf (accessed on 24 June 2020).

(C) 2020 by the authors. Licensee MDPI, Basel, Switzerland. This article is an open access article distributed under the terms and conditions of the Creative Commons Attribution (CC BY) license (http://creativecommons.org/licenses/by/4.0/). 